\title{
Ecological Models to Infer the Quantitative Relationship between Land Use and the Aquatic Macroinvertebrate Community
}

\author{
Minar Naomi Damanik-Ambarita ${ }^{1, *}$, Gert Everaert ${ }^{1,2}$ (D) and Peter L. M. Goethals ${ }^{1}$ \\ 1 Aquatic Ecology Research Unit, Department of Animal Sciences and Aquatic Ecology, Ghent University, \\ Coupure Links 653, Building F, 9000 Ghent, Belgium; gert.everaert@vliz.be (G.E.); \\ peter.goethals@ugent.be (P.L.M.G.) \\ 2 Flanders Marine Institute, Wandelaarkaai 7, 8400 Ostend, Belgium \\ * Correspondence: MinarNaomi.DamanikAmbarita@UGent.be or minardamanik@yahoo.com; \\ Tel.: +32-92-643-895
}

Received: 30 November 2017; Accepted: 8 February 2018; Published: 10 February 2018

\begin{abstract}
Land-use changes influence the ecological water quality. In spite of this knowledge, land-use information is often missing in ecological water quality studies. Therefore, in the present research, we selected 39 peer-reviewed model-based scientific papers that study the relationship between land use and aquatic macroinvertebrates. From the selected papers, we found that certain water bodies responded more to local land use, while other water bodies were more likely to be affected by catchment land use. Hence, combined land-use information from both the local scale and the catchment scale will provide a better understanding of the impact of land-use changes on the ecological water quality. To gain this knowledge, efforts need to be taken to acquire land-use information from field observations and remote sensing or a geographic information system (GIS) data source. Furthermore, we concluded on the benefits of using models to better understand the relationship between the ecological water quality and environmental variables. Depending on the aim of the study and the nature of the data, researchers can select the most suitable model to ensure fast analysis.
\end{abstract}

Keywords: ecological water quality; macroinvertebrates; land use; models

\section{Introduction}

Anthropogenic activities that are taking place upstream and in the surrounding surface waters can influence the water quality by altering its physico-chemical and hydromorphological characteristics [1,2]. There is a clear link between land use and water quality, either positive or negative. For example, urbanization, industries, and intensive agriculture activities may increase erosion and sediment accumulation [3-6], increase the input of chemicals, such as nitrogen and phosphorus $[4,5,7,8]$, and create a more homogeneous flow and bed substrate of streams [3,9]. The impact of land-use changes due to agriculture can be minimized by reducing the use of agrochemicals, e.g., in small-scale farms [10], or by applying crop rotation and conservation tillage systems [11,12]. The impact that land use poses on surface waters is not limited to river ecosystems [13,14], but also affects ponds [15] and lakes [16,17]. The change in the physico-chemical and hydromorphological characteristics of the impacted river or catchment will consequently affect the richness and abundance of aquatic organisms, such as fish [18,19], macroinvertebrates [20,21], and plants [22,23].

Despite the clear linkage between land use and water quality, land use was not always included in water quality studies. Many studies relating water quality and aquatic organisms only focused on water quality variables, such as physico-chemical characteristics and hydromorphological conditions [24,25]. 
Other studies only focused on the potential effects of a certain type of land use on the water quality (e.g., residential [26], agriculture [27], mining [16], and forest [28]) or the occurrence of certain aquatic organisms [29-31]. Restoration projects focused sometimes only on monitoring water chemistry or the change in hydromorphological conditions, instead of addressing land use as the main cause [32,33]. Previous studies performed by Berger et al. [34] at 184 German rivers quantified the benefit of the inclusion of land use in studying water quality to improve ecological quality from diffuse pollution. Shrestha et al. [35] and Bussi et al. [36] also included land use in their studies. Shrestha et al. [35] successfully studied related water yield and nutrient release into it in Onkaparinga catchment (Australia), while Bussi et al. [36] studied the water quality of the River Thames catchment (UK).

When land use is included in the study, it is important to consider its spatiotemporal aspects, because land use that takes place within different locations, sizes, and times provokes various biogeochemical and hydrological responses [1]. However, the spatial coverage of studies that assess the impact of land use varies largely. To date, there is no consensus on whether the impacts of land use are only present within the local or direct vicinity [3,37,38], within a certain buffer zone [39], or as wide as the catchment area $[40,41]$ of the surface water. Some researchers have studied the impacts of land use on the water quality based on a single monitoring campaign $[13,14]$ or based on a long time data-series, such as within three time periods of 1971, 1985, and 1999 [42], over 75 years [1], and over the past century [43]. Unfortunately, Tu [42], Pilgrim et al. [1], and McDonald et al. [43] only studied land-use impacts on physico-chemical characteristics of the water, thus the impact of land use on macroinvertebrates or other aquatic biotas is unidentified. Studies of land-use impact on water quality also vary in the applied methods of acquiring the land-use data. Several studies were based on field observations [44,45], geographic information system (GIS) data [1,40], or combined methods and sources $[13,46]$. Methods bring highly variable outcomes that are difficult to compare with each other.

Due to the complexity of aquatic ecosystems, water quality studies can be challenging. Aquatic ecosystems are influenced by multiple variables, and it is difficult to decide which variable to focus on in the studies. In this context, using ecological models for studying water quality can be beneficial [47-50]. Slevers et al. [51] used linear mixed effects models to assess trout response to the change in riparian conditions in North America, Europe, South America, and Australia, while Ferreira et al. [52] used partial least squares regression models to assess water quality degradation and biodiversity decline (fish and macroinvertebrates) as the consequence of anthropogenic pressures. Other models, such as random forest models for diatom [53], multiple regression for macroinvertebrates [34], and boosted regression trees for fish and macroinvertebrates [54], have also been used in ecological-related studies that integrated land-use data.

Based on published articles in Web of Science, we reviewed water quality studies where land use was determined to be a key stressor influencing the presence of aquatic organisms. We selected studies that implemented ecological models to infer and quantify the relation between macroinvertebrate communities and environmental variables in river ecosystems. We discuss how we shall better study the impacts of land use on macroinvertebrates in developing countries where available updated land-use information is limited. We also recommend an integrated approach of evaluating land-use impacts on macroinvertebrates. Throughout the manuscript, the term ecological water quality is used to define water quality based on aquatic organisms, especially macroinvertebrates.

\section{Materials and Methods}

The internationally peer-reviewed papers were accessed via the Web of Science for the period between 1955 and 23 May 2017. The search was performed by including the key words 'water quality', 'macroinvertebrate*', and 'river"' and excluding the key word 'diatom"' as topic, then continuing with the key word(s) 'land use" and 'model' ${ }^{* \prime}$ as topic and title, in substitution (Figure 1). During the search, we found that several papers had studied ecological water quality based on macroinvertebrates and diatoms. As our primary focus and expertise was on aquatic macroinvertebrates, we excluded papers that solely dealt with diatoms. Using 'land use' as key word(s) in the title resulted in 15 papers, while 
using 'model*' as a key word in the title resulted in 28 papers (Figure 1). Note that four papers among these 28 papers were also listed in the 15 papers. Hence, in total $39(=15+28-4)$ papers were retained that covered a wide range of internationally available studies related to our objectives.

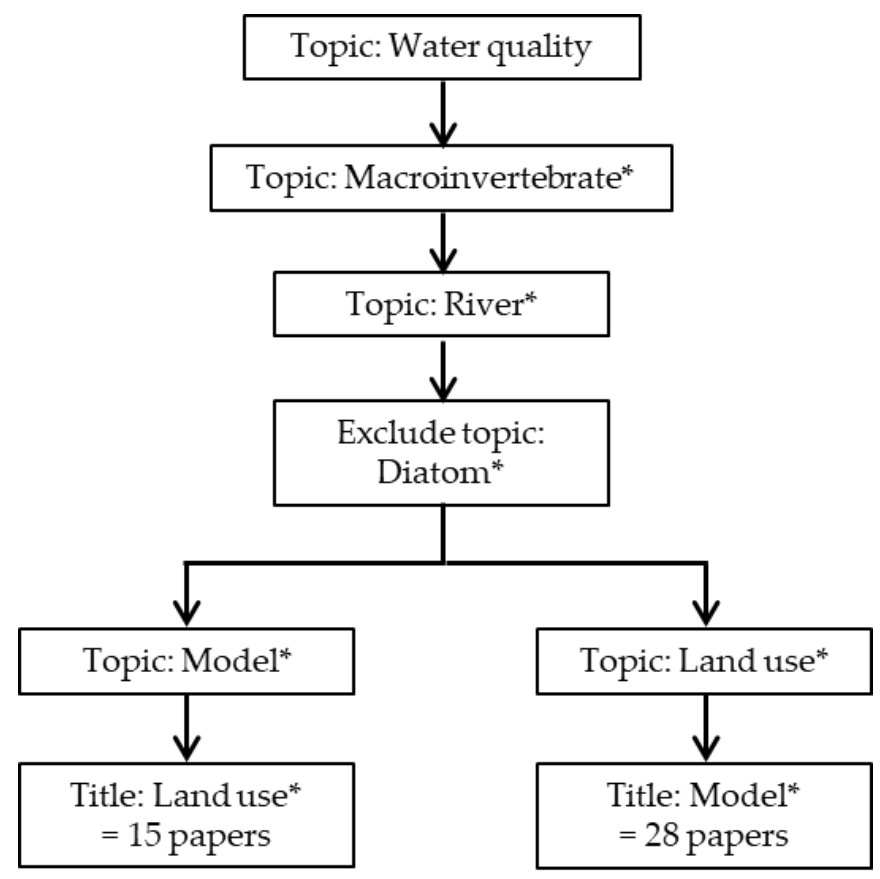

Figure 1. Scheme of search category and key word(s) for paper selection in the Web of Science and the number of resulting papers.

The papers were assessed in terms of input variables included in the models, spatial scale of land-use information, ecological community that is assessed, biological index used, type of ecological model, and country of study. A strengths, weaknesses, opportunities, and threats (SWOT) analysis was utilized to evaluate the use of models in ecological water quality studies and the inclusion of land-use information in the analysis. Finally, the methods were compiled to provide a recommendation for worldwide studies, especially in developing countries.

\section{Ecological Water Quality Studies and Land Use}

\subsection{Introduction}

Most of the 39 papers used macroinvertebrate data identified up to family level (19 papers, Table 1). Seventeen papers used macroinvertebrate data up to species or genus level for most taxa and up to family level for the remaining taxa, while two papers only used order level and one paper did not mention the level of identification. Macroinvertebrate data were collected either from national/regional databases (20 papers) or during tailor-designed sampling campaigns (19 papers). Macroinvertebrate sampling was done mainly using the kick-net method (13 papers) or the surber method (4 papers), while 2 papers did not mention the type of sampling they performed. Several papers studied macroinvertebrate data based on taxa richness (16 papers), using various biotic indices (17 papers), or various diversity indices, such as Simpson's diversity and the Shannon-Wiener index (2 papers), or a combination of biotic and diversity indices (4 papers). In one paper, the authors performed their assessment based on biological, physiological, and ecological macroinvertebrate traits [13], while in two other papers, the assessment was based on the functional feeding group $[55,56]$. 
Table 1. Macroinvertebrate data used in the selected papers; kick: kick net, surber: surber sampler, slack: slack sampler.

\begin{tabular}{|c|c|c|c|c|c|c|c|c|}
\hline \multicolumn{4}{|c|}{ Identification Level } & \multicolumn{2}{|c|}{ Data Source } & \multicolumn{3}{|c|}{ Biotic Index } \\
\hline Family Level & $\begin{array}{l}\text { Mostly Species or } \\
\text { Genus Level, Some } \\
\text { Up to Family Level }\end{array}$ & Order Level & No Information & Sampling (Kick, Surber) & $\begin{array}{l}\text { National/Regional } \\
\text { Databases }\end{array}$ & $\begin{array}{l}\text { No Biotic index, } \\
\text { Only Taxa Richness }\end{array}$ & $\begin{array}{l}\text { Biotic Index (e.g., } \\
\text { Hilsenhoff, EPT, } \\
\text { BMWP, ASPT) }\end{array}$ & $\begin{array}{c}\text { Diversity Indices } \\
\text { (Simpson's Diversity, } \\
\text { Shannon-Wiener } \\
\text { Index) }\end{array}$ \\
\hline $\begin{array}{l}\text { Abouali et al. [57], } \\
\text { Alemneh et al. [58], } \\
\text { Alvarez-Cabria et al. } \\
\text { [59], Baltazar et al. } \\
\text { [60], Cortes et al. [13], } \\
\text { [61], Einheuser et al. } \\
\text { [62], Erba et al. [63], } \\
\text { Forio et al. [64], Forio } \\
\text { et al. [65], Hrodey et } \\
\text { al. [66], Hughes et al. } \\
\text { [40], Mantyka-Pringle } \\
\text { et al. [67], Moreno et } \\
\text { al. [68], Pearson et al. } \\
\text { [55], Sanchez et al. } \\
\text { [69], Sheldon et al. } \\
\text { [70], Woznicki et al. } \\
\text { [71], Zhang et al. [72] }\end{array}$ & $\begin{array}{l}\text { Barton [73], } \\
\text { Bennetsen et al. [74], } \\
\text { Carlisle and Hawkins } \\
\text { [75], Carlisle and } \\
\text { Meador [76], Clapcott } \\
\text { et al. [77], Dahm and } \\
\text { Hering [54], Davies } \\
\text { and Jackson [78], Feio } \\
\text { et al. [79], Feio et al. } \\
\text { [80], Guse et al. [81], } \\
\text { Hawkins et al. [82], } \\
\text { Hawkins and Yuan } \\
\text { [83], Maloney and } \\
\text { Weller [84], Schmalz } \\
\text { et al. [41], Sueyoshi et } \\
\text { al. [31], Terrado et al. } \\
\text { [85], Weigel [56] }\end{array}$ & $\begin{array}{l}\text { Lock and } \\
\text { Goethals [86], } \\
\text { Lock and } \\
\text { Goethals [87] }\end{array}$ & $\begin{array}{l}\text { Van Sickle et al. } \\
\text { [88] }\end{array}$ & $\begin{array}{l}\text { Alemneh et al. [58] kick, } \\
\text { Baltazar et al. [60] kick, } \\
\text { Barton [73] kick, Cortes et } \\
\text { al. [13], } \\
\text { Damanik-Ambarita et al. } \\
\text { [61] kick, Erba et al. [63] } \\
\text { surber, Feio et al. [80] } \\
\text { kick, Forio et al. [64] kick, } \\
\text { Forio et al. [65] kick, } \\
\text { Hawkins et al. [82] } \\
\text { surber, Hrodey et al. [66] } \\
\text { Ekman dredge + kick + } \\
\text { surber, Lock and } \\
\text { Goethals [86] kick, Lock } \\
\text { and Goethals [87] kick, } \\
\text { Maloney and Weller [84] } \\
\text { kick, Moreno et al. [68] } \\
\text { surber, Pearson et al. [55] } \\
\text { kick, Schmalz et al. [41], } \\
\text { Sueyoshi et al. [31] surber, } \\
\text { Zhang et al. [72] kick }\end{array}$ & $\begin{array}{l}\text { Abouali et al. [57], } \\
\text { Alvarez-Cabria et al. } \\
\text { [59] kick, Bennetsen } \\
\text { et al. [74], Carlisle } \\
\text { and Hawkins [75] } \\
\text { slack, Carlisle and } \\
\text { Meador [76] slack, } \\
\text { Clapcott et al. [77] } \\
\text { kick + surber, Dahm } \\
\text { and Hering [54], } \\
\text { Davies and Jackson } \\
\text { [78], Einheuser et al. } \\
\text { [62], Feio et al. [79] } \\
\text { kick, Guse et al. [81], } \\
\text { Hawkins and Yuan } \\
\text { [83], Hughes et al. } \\
\text { [40], Mantyka-Pringle } \\
\text { et al. [67], Sanchez et } \\
\text { al. [69], Sheldon et al. } \\
\text { [70], Terrado et al. } \\
\text { [85], Van Sickle et al. } \\
\text { [88], Weigel [56], } \\
\text { Woznicki et al. [71] }\end{array}$ & $\begin{array}{l}\text { Alemneh et al. [58], } \\
\text { Bennetsen et al. [74], } \\
\text { Carlisle and Hawkins } \\
\text { [75], Carlisle and } \\
\text { Meador [76], Dahm } \\
\text { and Hering [54], } \\
\text { Davies and Jackson } \\
\text { [78], Feio et al. [79], } \\
\text { Feio et al. [80], Guse } \\
\text { et al. [81], Hawkins et } \\
\text { al. [82], Hawkins and } \\
\text { Yuan [83], Lock and } \\
\text { Goethals [86], Lock } \\
\text { and Goethals [87], } \\
\text { Mantyka-Pringle et al. } \\
\text { [67], Schmalz et al. } \\
\text { [41], Sueyoshi et al. } \\
\text { [31], }\end{array}$ & $\begin{array}{l}\text { Abouali et al. [57], } \\
\text { Alvarez-Cabria et al. } \\
\text { [59], Baltazar et al. } \\
\text { [60], Barton [73], } \\
\text { Clapcott et al. [77], } \\
\text { Cortes et al. [13], } \\
\text { Damanik-Ambarita et } \\
\text { al. [61], Einheuser et } \\
\text { al. [62], Erba et al. } \\
\text { [63], Forio et al. [64], } \\
\text { Forio et al. [65], } \\
\text { Hrodey et al. [66], } \\
\text { Hughes et al. [40], } \\
\text { Maloney and Weller } \\
\text { [84], Pearson et al. } \\
\text { [55], Sanchez et al. } \\
\text { [69], Sheldon et al. } \\
\text { [70], Van Sickle et al. } \\
\text { [88], Weigel [56], } \\
\text { Woznicki et al. [71], } \\
\text { Zhang et al. [72] }\end{array}$ & $\begin{array}{l}\text { Baltazar et al. [60], } \\
\text { Erba et al. [63], } \\
\text { Moreno et al. [68], } \\
\text { Pearson et al. [55], } \\
\text { Terrado et al. [85], } \\
\text { Weigel [56] }\end{array}$ \\
\hline
\end{tabular}


The compiled papers suggested that more studies addressed urban and industrial land uses. Moreover, urban and industrial areas pose more negative consequences toward aquatic ecosystems (seven papers), compared to agricultural areas (five papers). A combination of agricultural and urban was also considered to negatively influence the aquatic ecosystems (three papers, Table 2). This result corroborated with the report published by the United Nations Environment Program (UNEP, Table A1). The UNEP has published a list of economic activities with their effects on aquatic ecosystems where industries were identified to pose the most threats toward aquatic ecosystems [89]. However, many papers only included land-use information to support the analysis but did not specifically study land-use effect on the aquatic ecosystems. Moreover, several papers did not mention land-use classification following the typical classification system (e.g., urban, agricultural, and forest). Depending on the purpose of the study, land use was sometimes classified into more detailed classes (e.g., heavy and light pastoral [77]).

Studies on the effect of land use on ecological water quality in developing countries are still limited. From the 39 selected papers, only eight studies were performed in developing countries (Table A2). Four of these studies were performed in South America, three studies were done in Asia, and one study was done in Africa. However, it is possible that most studies in developing countries have been published in local journals that are not accessible via the Web of Science portal.

Most of the 39 studies mainly focused on the local or riparian scale, and only $25 \%$ of the papers studied land-use effects at both local or riparian and catchment scales. Among the 39 papers, only two papers included land-use change (temporal aspect, Table A2) and five papers studied effects of land-use change by creating a scenario of future conditions (Table A2).

The land-use information is collected in different ways. In addition to the conventional way of field observation, other observation methods and data sources for acquiring land-use data exist (Table A3). For example, land-use data have been collected via remote sensing [62,85]; GIS sources [67,80], an available national database; or a combination of the methods and sources (Table A3). A national database and a GIS can be available in various forms, e.g., shape file and digital map; however, this was not always specified in the selected papers. Hence, both were considered as separate sources in Table A3. By combining different methods and data sources, the area coverage of land-use information can be enlarged beyond the dimensions of field observation.

As explained by Kuemmerle et al. [90], the limited availability of comparable land-use data is due to varying land-use categories between disciplines. Another reason is that adequate approaches to quantify land use and integrate various data sources are often missing. The problem is observed more in developing countries, where sometimes countries lack consistent data collection and data-sharing frameworks among institutions [90]. 
Table 2. Effects of land use based on the selected published papers.

\begin{tabular}{|c|c|c|c|}
\hline \multirow{2}{*}{ Used Land-Use Information } & \multicolumn{3}{|c|}{ Land-Use Effects } \\
\hline & Positive & Negative & Not Defined or Not Studied \\
\hline Urban, industrial & & $\begin{array}{l}\text { Alemneh et al. [58], Baltazar et al. [60], } \\
\text { Carlisle and Meador [76], Cortes et al. [13], } \\
\text { Lock and Goethals [87], Lock and Goethals } \\
\text { [86], Sanchez et al. [69] }\end{array}$ & \\
\hline Agricultural (arable, pasture, orchard, etc.) & & $\begin{array}{l}\text { Barton [73], Hrodey et al. [66], Pearson et al. } \\
\text { [55], Sueyoshi et al. [31], Weigel [56] }\end{array}$ & \\
\hline Forest & Sheldon et al. [70] & & \\
\hline Agricultural + urban & & $\begin{array}{l}\text { Maloney and Weller [84], Van Sickle et al. [88], } \\
\text { Zhang et al. [72] }\end{array}$ & \\
\hline Land use is divided into clear classes & & & $\begin{array}{l}\text { Abouali et al. [57], Alvarez-Cabria et al. [59], } \\
\text { Clapcott et al. [77], Dahm and Hering [54], } \\
\text { Damanik-Ambarita et al. [61], Erba et al. [63], } \\
\text { Feio et al. [79], Feio et al. [80], Forio et al. [64], } \\
\text { Forio et al. [65], Hawkins et al. [82], } \\
\text { Mantyka-Pringle et al. [67], Woznicki et al. [71] }\end{array}$ \\
\hline Land use classification is not provided & & & $\begin{array}{l}\text { Bennetsen et al. [74], Davies and Jackson [78], } \\
\text { Hawkins and Yuan [83], Moreno et al. [68] }\end{array}$ \\
\hline Scenario best management practices & $\begin{array}{l}\text { Einheuser et al. [62], Hughes et al. [40], } \\
\text { Schmalz et al. [41], Terrado et al. [85] }\end{array}$ & & \\
\hline Scenario crop rotations & & Guse et al. [81] & \\
\hline $\begin{array}{l}\text { Mixed use (combination of agricultural, } \\
\text { residential, forest, etc.) }\end{array}$ & & Carlisle and Hawkins [75] & \\
\hline
\end{tabular}




\subsection{Local or Riparian Land-Use Scale}

Most of the selected papers included land-use information at local or riparian scale as this information can be relatively easily collected through field observations during a dedicated sampling campaign $[58,60,73]$ (Table 3). Here, we considered a riparian zone (as described by Crétaz and Barten [91]) to be comprised of a stream valley and terrace slope, including stream channel, floodplain, and parts of adjacent uplands where aquatic and terrestrial ecosystems interact. A riparian zone acts as storage for flood waters, organic material, and nutrients that are transported from uplands to streams. However, the function of a riparian zone varies according to residence time of pollutants in the buffer, the thickness of the unsaturated zone, and the upland land use [91]. Having defined our view on the riparian zone, note that in scientific literature the term local was sometimes used for riparian land use. Therefore, in this review we have combined local and riparian into one scale. Here, we provide examples of scales from selected papers and other land-use-related studies (Table 3). Several studies have confirmed the importance of local land use on the water quality [61]. For example, Sanchez et al. [69] studied the importance of urban and Hawkins and Yuan [83] studied the influence of agricultural areas where human interventions are generally expanded until the edge of the streams. However, many studies included the information of local land use but did not specifically assess its potential effects on the water quality $[78,82]$ or did not find its importance on the ecological water quality after analyses [79].

Table 3. Various scales in quantifying land use at local or riparian and catchment scales from selected papers and other land-use-related studies: unless otherwise mentioned, the local scale is not described as length, width, or radius; scale is given as length $\times$ width.

\begin{tabular}{|c|c|c|c|}
\hline $\begin{array}{l}\text { Local or Riparian Scale } \\
\text { (m) }\end{array}$ & Authors & Catchment Scale $\left(\mathrm{km}^{2}\right)$ & Authors \\
\hline 30 & Abouali et al. [57], Hrodey et al. [66] & 17 & Rios-Touma et al. [92] \\
\hline 1000 radius & Cortes et al. [13], Feio et al. [80] & 6378 & Waite [93] \\
\hline 150 radius & Molina et al. [94] & 33 & Molina et al. [94] \\
\hline $10,100,250,500,1000,2000$ & Usio et al. [95] & 447 & Lee et al. [96] \\
\hline $50,100,250,500,1000,2500$ & Thornhill et al. [15] & 5896 & Wen et al. [97] \\
\hline 250 radius & de Morais et al. [98] & 181 & $\begin{array}{l}\text { Raymond and } \\
\text { Vondracek [99] }\end{array}$ \\
\hline $200 \times 300$ & Jayawardana et al. [100] & 765 & Jayawardana et al. [100] \\
\hline $\begin{array}{c}500-, 1000-, 2500-, 5000 \times \\
100\end{array}$ & Dahm and Hering [54] & 173 & Merriam et al. [101] \\
\hline 100,1000 & Meyer et al. [102] & 35 & Carvalho et al. [103] \\
\hline 500 length or radius & $\begin{array}{l}\text { Erba et al. [63], Pearson et al. [55], } \\
\text { Mantyka-Pringle et al. [67] }\end{array}$ & 2000 & Bellucci et al. [104] \\
\hline 30,120 width & Van Sickle et al. [88] & 9162 & Park et al. [39] \\
\hline
\end{tabular}

\subsection{Catchment or Regional Land-Use Scale}

The effect of land use at catchment scale has not been studied as much as the impact of land use at local or riparian scale (only seven out of 39 papers studied it), despite the potential impact that land use at catchment scale poses on the ecological water quality. Since the area coverage of a catchment can be relatively large (i.e., of a large river), it requires relatively more time and human resources to assess the land use through field observation. Remote sensing via satellite images and aerial surveys [77] and available GIS data [31] are common methods and sources in assessing the catchment land use. The scale of catchment land use varies and is not always mentioned (examples in Table 3). Some studies did not classify the catchment land use or did not study specifically its effects on the ecological water quality [59]. However, Carlisle and Hawkins [75] and Carlisle and Meador [76] successfully defined land-use effects at catchment scale on the macroinvertebrate. They found the degree of land-use effects following a sequence of land-use classes: mixed land use and urban were reported to have the most adverse effects, whereas forests posed a positive effect. Lastly, Woznicki et al. [71] assessed and 
classified the catchment land use. However, their study did not assign a key importance to land use and therefore they focused on water quality variables instead.

\subsection{Recommendation for Integrated Local or Riparian and Catchment or Regional Land-Use Scales}

Since the effectiveness of local or riparian areas to store flood waters, organic material, and nutrients depends on the catchment's characteristics and regional climate [91], studies on the impact of land-use changes on aquatic communities should integrate both local or riparian and catchment land-use information. For example, Lowrance et al. [105] studied the effectiveness of a riparian forest buffer at the Chesapeake Bay watershed based on nutrient transport from an agricultural watershed into the coastal plain and the Chesapeake Bay. The diverse and complex relation between local or riparian and catchment land-use scales was the reason why 11 out of 39 papers studied the impacts of land use at both riparian and catchment scales. The complementary benefit of combining both land-use scales can be seen from the studies done by Weigel [56] and Cortes et al. [13]. Weigel [56] found out that the influence of each scale to determine macroinvertebrate distribution was dominant at certain parts of his study area, but not exclusive of each other. However, Van Sickle et al. [88] found out that riparian land use explained the land-use impacts better than catchment land use, while Sheldon et al. [70] concluded the opposite.

When field observation and either remote-sensing observation or GIS data are combined, land-use data become more informative and area coverage can be enlarged more than what is possible through field observation alone. In the future, more land-use data will become available for developing countries through open source data, especially with the improvement of satellite images, aerial surveys, and digital data globally [106]. For example, Baltazar et al. [60] could access the land-use data of the Niyugan River Sub-watershed, The Philippines, through Google Earth; while Moreno et al. [68] accessed the land-use data of the das Velhas River, Brazil, through digital cartography data. Similarly, remote sensing was done using Google Earth and the GIS data were accessed from the Ministerio de Agricultura, Ganadería, Acuacultura y Pesca (MAGAP) of Ecuador to collect land-use data of the Guayas river basin, Ecuador (unpublished paper). This way, developing countries nowadays have some modest initial access to land-use data and thus have the possibility to improve their ecological water quality studies in relation to land use. For future studies, we recommend combining field observations, remote sensing, and whenever possible GIS data sources for local or riparian land use. For catchment land use, remote sensing can be utilized and GIS data sources can be accessed. By combining methods and sources, land use can be quantified for both the local and catchment land-use scales.

\subsection{Land-Use Change}

Only two out of the 39 papers included temporal aspects of land use, and both papers had similar conclusions. Maloney and Weller [84] found that past land use occurring 50 years ago still influences the present day conditions of streams. Similarly, Schmalz et al. [41] also found negative effects of deforestation on the streams and aquatic ecosystems within a 30-year period.

Besides land-use change due to anthropogenic activities, water-quality variables may also change due to natural processes [91,107] and land-use change due to extreme events or natural disasters, such as climate change, floods, fires, and earthquakes [108-111]. For example, an increase in ammonium-N and nitrate- $\mathrm{N}$ concentrations of the Swedish streams and a decrease in aquatic macroinvertebrate richness and abundance were observed after a flashflood event [112]. Another example is wildfire together with post-wildfire rainfall on riparian vegetation. Besides altering microclimatic conditions, increasing runoff, and enhancing erosion, wildfire and post-wildfire rainfall may consequently decrease the richness and abundance of aquatic biota [113].

However, data on past land-use changes are often not available or not stored compared to the current day situation and in these cases the effect of land-use change is difficult to quantify. The poor availability of land-use change information is probably the reason why several studies used land-use 
scenarios to study land-use impacts using the current situation but without information of past land use $[40,62]$. Indeed, the need for land-use change information depends on the purposes of the studies and is not necessarily required when the study purpose is to assess the effect of current land use. We recommend local and regional government in the developing countries to store their land-use information. Data from past or current surveys and projects should be added to local or regional databases, and the databases need to be updated and completed for other parts of the country. To update their land-use data, developing countries can also access global databases that are continuously developing and are freely available (e.g., GRASS GIS [114]). To be able to track and study changes (e.g., in the perspective of climate change or agro-economic developments), it is important to have both historical and recent data available in these databases.

\section{Use of Models in Ecological Water Quality Studies}

\subsection{Input Variables}

When studying the impact of land use on macroinvertebrates, different types of input variables were used in the models of the selected papers (Table 4). Geomorphological variables (e.g., elevation, river banks, and sediment type) are the most common type of variables being used in ecological water quality studies (37 papers), followed by physico-chemical (e.g., nutrients and pH; 35 papers) and hydrological variables (e.g., annual discharge and flow; 23 papers). Geomorphological and hydrological variables can be gathered via field observation and in situ sampling. Both geomorphological and hydrological variables can provide information on anthropogenic alteration on the water body. Physico-chemical variables are easily changed within a short period of time; therefore, the change in water quality can be relatively easily detected based on long-term data originating from regular monitoring campaigns. Such long-term data-series are also required to unravel the variability due to land-use changes from the natural variability of the aquatic ecosystem. Some authors were interested in studying certain types of variables only; however, most papers combined different types of variables (Table 4).

Table 4. Type of input variables.

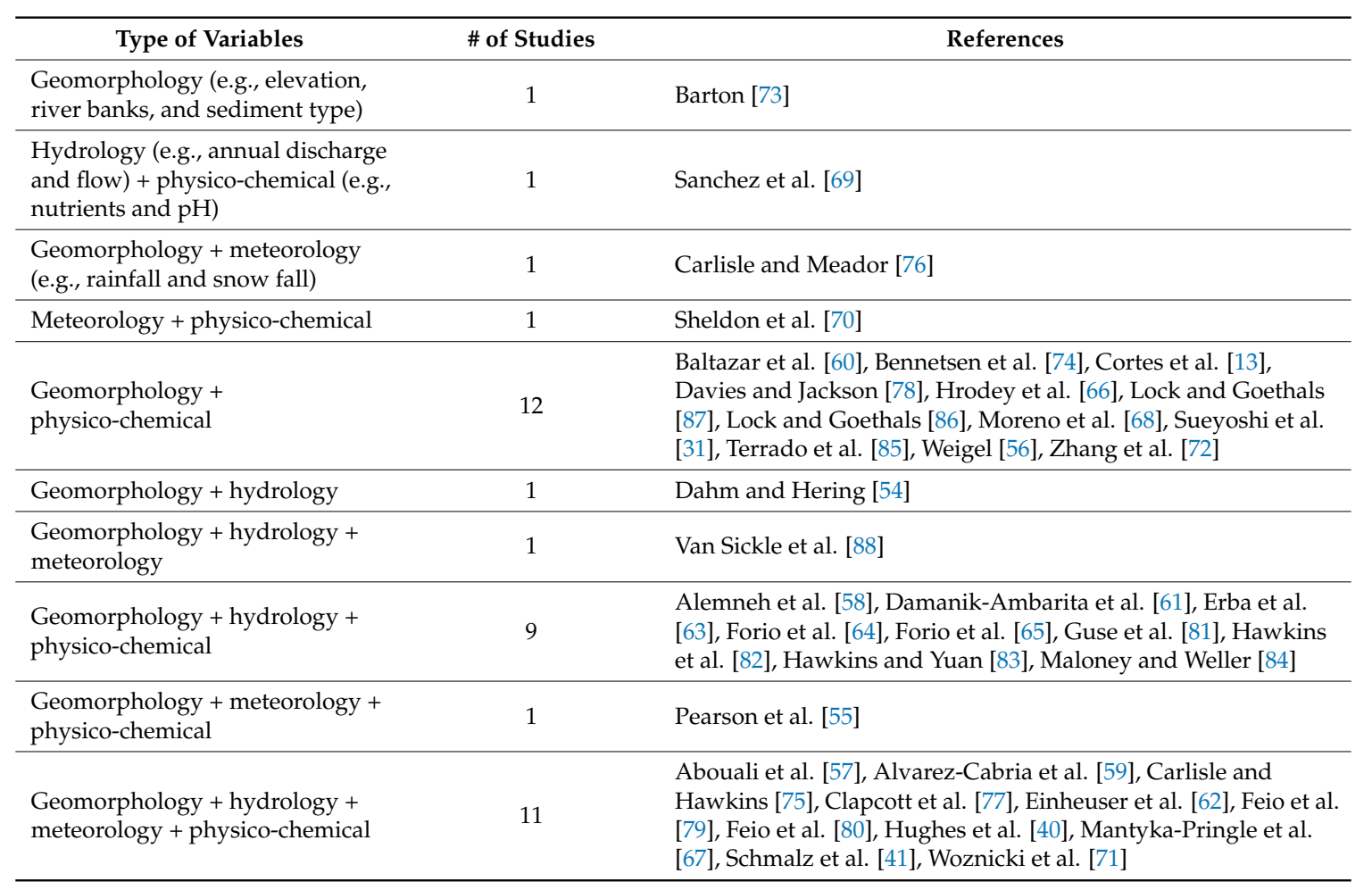




\subsection{Ecological Models}

The selected papers used different mathematical and statistical techniques to identify, assess, and quantify the effect of land-use changes on the aquatic community (Table 5). Both multivariate techniques and decision trees have been often used to predict the presence of macroinvertebrate taxa based on environmental variables. Several papers used more than one model from the same technique or a combination of different types of models in their analyses (Table 5).

Table 5. Types of models used in ecological water quality studies.

\begin{tabular}{|c|c|c|}
\hline Type of Models & \# of Studies & References \\
\hline $\begin{array}{l}\text { Multivariate analyses (e.g., } \\
\text { ordination, species distribution, } \\
\text { community composition, Bayesian } \\
\text { belief networks) }\end{array}$ & 10 & $\begin{array}{l}\text { Barton [73], Bennetsen et al. [74], Davies and Jackson [78], Feio } \\
\text { et al. [79], Feio et al. [80], Forio et al. [64], Hawkins et al. [82], } \\
\text { Hawkins and Yuan [83], Hrodey et al. [66], Moreno et al. [68], } \\
\text { Van Sickle et al. [88] }\end{array}$ \\
\hline $\begin{array}{l}\text { Regression analyses (e.g., linear, } \\
\text { multiple, mixed, structural } \\
\text { equation) }\end{array}$ & 4 & $\begin{array}{l}\text { Damanik-Ambarita et al. [61], Erba et al. [63], Maloney and } \\
\text { Weller [84], Sheldon et al. [70] }\end{array}$ \\
\hline $\begin{array}{l}\text { Decision trees (e.g., random forest, } \\
\text { regression trees, fuzzy) }\end{array}$ & 4 & $\begin{array}{l}\text { Alvarez-Cabria et al. [59], Dahm and Hering [54], Forio et al. } \\
\text { [65] }\end{array}$ \\
\hline Ordination + regression analyses & 6 & $\begin{array}{l}\text { Alemneh et al. [58], Carlisle and Meador [76], Sanchez et al. [69], } \\
\text { Sueyoshi et al. [31], Weigel [56], Zhang et al. [72] }\end{array}$ \\
\hline $\begin{array}{l}\text { Ordination }+ \text { decision trees } \\
\text { analyses }\end{array}$ & 2 & Carlisle and Hawkins [75], Mantyka-Pringle et al. [67] \\
\hline $\begin{array}{l}\text { Decision trees }+ \text { regression } \\
\text { analyses }\end{array}$ & 2 & Clapcott et al. [77], Einheuser et al. [62] \\
\hline $\begin{array}{l}\text { Ordination }+ \text { regression }+ \text { decision } \\
\text { trees analyses }\end{array}$ & 3 & Cortes et al. [13], Lock and Goethals [87], Lock and Goethals [86] \\
\hline $\begin{array}{l}\text { Software programming model } \\
\text { (e.g., Stella visual programming } \\
\text { and simulation, SWAT } \\
\text { eco-hydrological model, InVEST } \\
\text { habitat quality module) }\end{array}$ & 3 & Baltazar et al. [60], Guse et al. [81], Terrado et al. [85] \\
\hline $\begin{array}{l}\text { Software programming + } \\
\text { ordination }\end{array}$ & 2 & Schmalz et al. [41], Woznicki et al. [71] \\
\hline $\begin{array}{l}\text { Software programming + } \\
\text { regression }\end{array}$ & 1 & Hughes et al. [40] \\
\hline $\begin{array}{l}\text { Software programming }+ \text { decision } \\
\text { trees }+ \text { regression }\end{array}$ & 1 & Abouali et al. [57] \\
\hline Propensity modelling + regression & 1 & Pearson et al. [55] \\
\hline
\end{tabular}

Multivariate analyses were most often used to study the relationship between water quality and environmental variables. Multivariate analyses are useful in analyzing the structure or pattern in the data together with the contributions of the variables. These techniques are useful for a dataset that contains a large number of variables [115-117]. Ordination, a common multivariate technique, integrates regression and permutation methods and provides easy-to-read graphical outputs [116,117]. Due to their relative simplicity, they have been often used in ecological water quality studies. For example, Carlisle and Meador [76] used multiple discriminant analysis, Feio et al. [79] used multi-dimensional scaling and stepwise multiple discriminant function analysis, and Mantyka-Pringle et al. [67] used principal components analysis. Some disadvantages of these techniques are that the outputs can be difficult to interpret and that associations among variables and distribution patterns do not inherently imply causality [118].

The second-most frequently applied methods in the selected papers are regression-based techniques, comprising linear, polynomial, multiple, and non-linear regression. Regression analysis estimates parameter values and standard errors of a given dataset by analyzing the relationship between the response and the explanatory variables $[116,117,119]$. From the selected papers, partial least square regression was used to analyze the ecological water quality of the Flint River watershed in 
Michigan, USA, by Abouali et al. [57], while a generalized linear model was used to study the water quality of Alto Minho region, Portugal, by Hughes et al. [40]. Linear and logistic regression techniques are useful to develop a precise and concise model from a large dataset. However, linear regression cannot handle missing values, while logistic regression will divide variables with missing values into classes [120].

Other types of ecological models that are commonly applied in ecological water quality studies are decision tree models based on classification and regression trees (CART). Decision tree models are simple techniques that can provide a clear structure of the data having many explanatory variables and the type of interactions between variables. The basic principle of decision trees lies in its binary recursive partitioning, which is splitting the data along coordinate axes of the explanatory variables. Classification trees are applicable when the response variable is nominal, while regression trees are applicable when the response variable is continuous $[116,117,121]$. Decision trees are also able to deal with relatively small datasets [122]. For example, Dahm and Hering [54] utilized boosted regression tree to identify the recolonization of source sites for fish and macroinvertebrates in Germany, while Lock and Goethals [87] used classification trees and random forest to predict the occurrence of Plecoptera in Belgium. Despite their simplicity and ability to deal with datasets containing many variables, decision trees are not robust and should be avoided when there are only few observations in the data [120].

A combination of different model types, the so-called ensemble methods, was also proven to be beneficial in ecological water quality studies. Alemneh et al. [58] combined multiple regression analysis and canonical correspondence analysis to identify environmental disturbance affecting macroinvertebrate communities in the Upper Blue Nile, Ethiopia. Analysis of covariance, random forest, and boosted regression tree were utilized by Clapcott et al. [77] to predict the expected reference condition for macroinvertebrate communities in New Zealand. Stepwise linear regression in combination with adaptive neuro-fuzzy inference systems were used to define the relationship between macroinvertebrates and environmental variables in Saginaw River watershed, USA [62]. Depending on the purpose, the application of ensemble methods can improve the quality of the results.

\subsection{Recommendation for Statistical Analysis and Model Selection}

Researchers studying the effect of land-use changes on the ecological water quality can rely on a myriad of ecological models or statistical analyses. The selection of the type of analysis to be used depends on the nature of the data (the type of response and explanatory variables) and the aim of the study. Model selection can also depend on the experience of the modeler because no model can be considered as the best option in every situation [122]. In a regression-based model, the selected model should fit best to the data and produce the least unexplained variation, while bearing in mind the parsimony principle and that all model parameters are statistically significant. Several models may explain a given dataset equally well, while in other cases no single best model can explain a dataset [116,117]. The provided guidelines here on data exploration and model selection serve as a recommendation on how analysis can be done in ecological water quality studies.

Zuur et al. [123] have formulated a scheme for various data exploration techniques, which is a very important step before applying a model (Table 6). Not every dataset requires each step, because different models require different assumptions. Without having the ambition to give a full overview on how to perform a data analysis (for that we refer to specific books, e.g., Witten and Frank [124] and Zuur et al. [117]), a process, for example a histogram analysis, is not required prior to principal component analysis (PCA). Similarly, normality and homogeneity do not need to be checked before developing regression models, since normality and homogeneity can be verified using the residuals produced by the regression models [123]. 
Table 6. Scheme for data exploration techniques. Y: response variable, X: explanatory variable [123].

\begin{tabular}{cc}
\hline Purpose & Technique \\
\hline Checking for outliers in Y \& & boxplot and Cleveland dotplot \\
Homogeneity Y & conditional boxplot \\
Normality Y & histogram or QQ-plot \\
Zero trouble $Y$ & frequency plot or corrgram \\
Collinearity X & variance inflation factor (VIF), scatterplots, correlations and \\
Relationships Y \& X & principal component analysis (PCA) \\
Interactions & (multi-panel) scatterplots, conditional boxplots \\
Independence $Y$ & coplots \\
\end{tabular}

When the aim of the study is only to understand the data, standard inferential statistics can be applied to get the statistics of the data [124]. In many cases, we also need to understand the structure and the underlying causal relationship of the data (descriptive methods) or to find an association and make predictions for future observations (predictive methods). Prior to modelling, the aim of the study must be specified to optimize the criterion of interest. Since both descriptive and predictive methods have a statistical background, a model will possess some level of explanatory and predictive accuracy $[124,125]$. Therefore, both explanatory and predictive qualities of the models need to be retained and reported [125]. Here, we provide the classification (Table 7) and comparison (Table 8) of various descriptive and predictive models based on Tuffery [120] to help in selecting an appropriate model for analysis. Table 8 summarizes the advantages and disadvantages of descriptive and predictive modelling in terms of the required assumptions regarding the problem to be solved, the capacity of the model in treating the data exhaustively within a reasonable period for all cases, and the possibility of the model to handle heterogeneous or incomplete data [120]. For a more detailed explanation on a specific method, we refer the readers to Tuffery [120], Van Echelpoel et al. [122], Berk [121], and Zuur [126]. 
Table 7. Classification of descriptive and predictive modelling and purposes/examples of using them; grey background shows methods that integrate statistics and data analysis [120]; PLS: partial least squares, (M)ANOVA: (multivariate) analysis of variance, (M)ANCOVA: (multivariate) analysis of covariance.

\begin{tabular}{|c|c|c|c|c|}
\hline Type & Family & Sub-Family & Algorithm & Purposes/Examples of Use \\
\hline \multirow{8}{*}{ Descriptive models } & \multirow{5}{*}{ Geometrical models } & Factor analysis & Principal component analysis (PCA) & $\begin{array}{l}\text { Finding predictors for macroinvertebrate } \\
\text { composition [13] }\end{array}$ \\
\hline & & & $\begin{array}{l}\text { Correspondence analysis (CA), multiple } \\
\text { correspondence analysis (MCA) }\end{array}$ & $\begin{array}{l}\text { CA to understand the distribution of } \\
\text { macroinvertebrate taxa among sites [127] }\end{array}$ \\
\hline & & Cluster analysis & $\begin{array}{l}\text { Partitioning methods (moving centres, } \\
\text { k-means, dynamic clouds, k-medoids, etc.) }\end{array}$ & Classifying reference sites [82] \\
\hline & & & Hierarchical methods (agglomerative, divisive) & $\begin{array}{l}\text { Macroinvertebrate classification into biologically } \\
\text { similar groups [76] }\end{array}$ \\
\hline & & $\begin{array}{l}\text { Cluster analysis + dimension } \\
\text { reduction }\end{array}$ & Neural clustering (Kohonen maps) & Determining macroinvertebrate distribution [128] \\
\hline & Combinatorial models & & Clustering by aggregation of similarities & \\
\hline & \multirow{2}{*}{ Logical rule-based models } & \multirow{2}{*}{ Link detection } & Search for association rules & \\
\hline & & & Search for similar sequences & \\
\hline \multirow{7}{*}{ Predictive models } & Logical rule-based models & Decision trees & Decision trees & $\begin{array}{l}\text { Classification and regression trees to define trait } \\
\text { and tolerance values that distinguished taxa } \\
\text { presence [75] }\end{array}$ \\
\hline & \multirow{5}{*}{$\begin{array}{l}\text { Models based on mathematical } \\
\text { functions }\end{array}$} & Neural networks & $\begin{array}{l}\text { Supervised learning networks (perceptron, } \\
\text { radial basis function network, etc.) }\end{array}$ & $\begin{array}{l}\text { Predicting macroinvertebrate occurrence based or } \\
\text { environmental variables [129] }\end{array}$ \\
\hline & & $\begin{array}{l}\text { Parametric or semi-parametric } \\
\text { models }\end{array}$ & $\begin{array}{l}\text { Continuous dependent variable: linear } \\
\text { regression, ANOVA, MANOVA, ANCOVA, } \\
\text { MANCOVA, general linear model (GLM), PLS } \\
\text { regression }\end{array}$ & $\begin{array}{l}\text { ANOVA to determine differing average values } \\
\text { among steams [75], PLS to refine selection of } \\
\text { predictors after PCA [13] }\end{array}$ \\
\hline & & & $\begin{array}{l}\text { Qualitative dependent variable: Fisher's } \\
\text { discriminant analysis, logistic regression, PLS } \\
\text { logistic regression }\end{array}$ & $\begin{array}{l}\text { Discriminant analysis to select environmental } \\
\text { variables estimating probability of a site belongs to } \\
\text { a group [76] }\end{array}$ \\
\hline & & & Count dependent variable: log-linear model & \\
\hline & & & $\begin{array}{l}\text { Continuous, discrete, count or qualitative } \\
\text { dependent variable: generalized linear model } \\
\text { (GLM), generalized additive model (GAM) }\end{array}$ & $\begin{array}{l}\text { GLM to identify and quantify interactions betweer } \\
\text { drivers and response variables [40] }\end{array}$ \\
\hline & Prediction without model & Probabilistic analysis & $\mathrm{k}$ nearest neighbours & $\begin{array}{l}\text { Predicting macroinvertebrate presence in a river } \\
{[130]}\end{array}$ \\
\hline
\end{tabular}


Table 8. Comparison of methods based on Tuffery [120]; CHAID: Chi-squared automatic interaction detector.

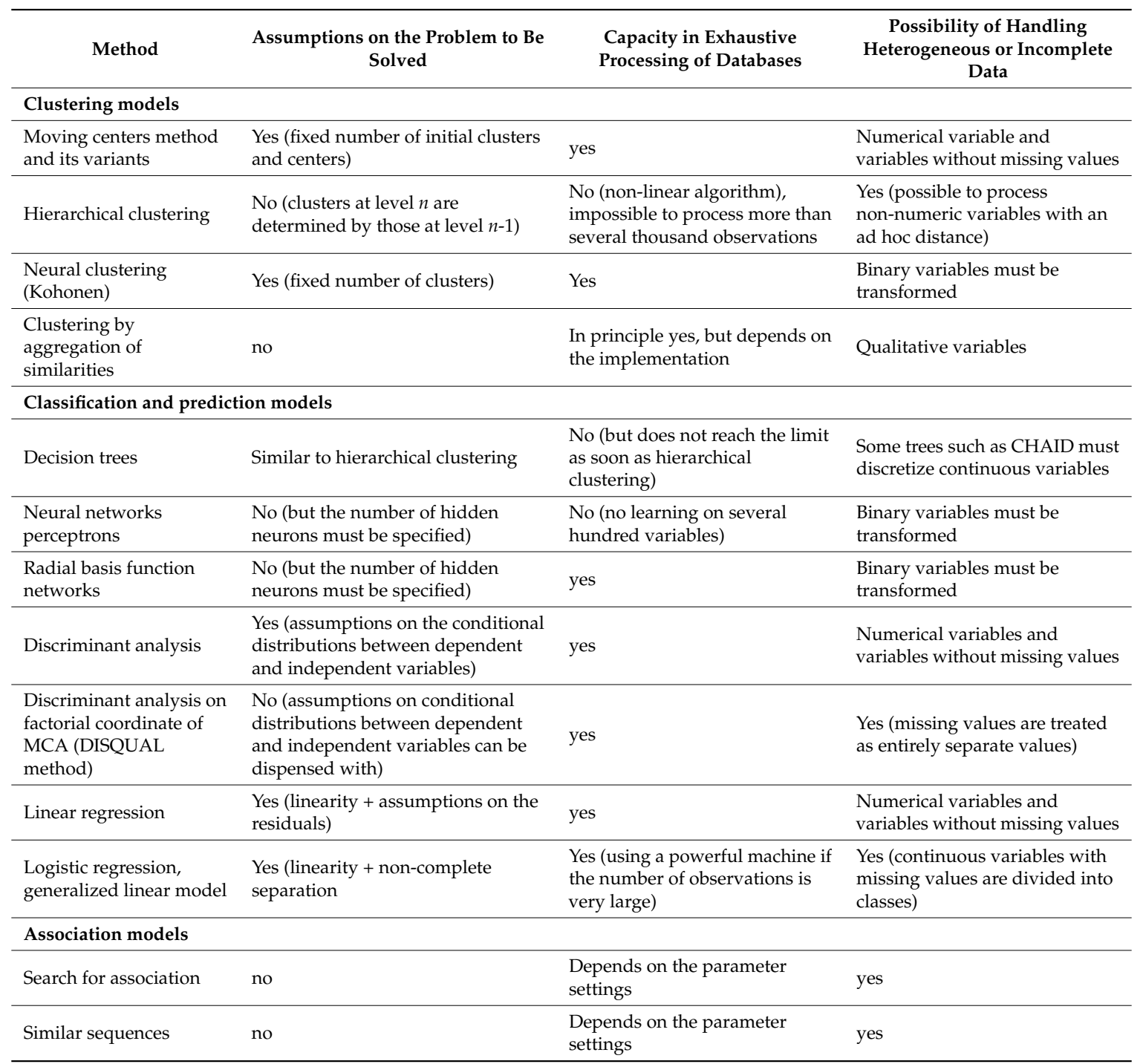

Another modelling type is mechanistic modelling, that derives the relationships between significant variables based on theories and principles that govern the studied system. The resulting model is given in mathematical equations. Examples for surface water are modelling of discharges from a wastewater treatment plant, industries, and storm water; agricultural/urban runoff; and a food chain [131]. Paillex et al. [132] and Schuwirth et al. [49] showed the use of such mechanistic models in ecological water quality studies. Mechanistic models allowed them to understand the mechanism behind the presence of taxa based on a combination of traits and environmental conditions [49,132]. Nevertheless, these mechanistic models have disadvantages. Besides the required long process in building such a mathematical model, there is no guarantee that the mechanistic explanation of the model is correct [131]. Especially in ecological studies, the available trait information that is necessary in a mathematical model might not be complete, and there is a possibility that an important variable required to understand the system is missing $[49,132]$. With the complexities and uncertainties of aquatic ecosystems, it is not surprising that this technique is not as popular as descriptive and predictive models. However, it is not our intention to provide a lengthy discussion on mechanistic models. For those interested, we refer to Nirmalakhandan [131]. 
For practicality, we also list some guidance on typical ecological models based on the nature of the response variable (Table 9), adapted from Guisan and Zimmermann [133].

Table 9. Statistical approaches for three types of response variables: quantitative, semi-quantitative, and qualitative [133]; WA: weighted averaging, LS: least squares, LOWESS: locally weighted scatterplot smoothing, GLM: generalized linear model, GAM: generalized additive model, PO: proportional odds, CR: continuous regression, MLC: maximum-likelihood classification, DFA: discriminant function analysis.

\begin{tabular}{|c|c|c|c|}
\hline $\begin{array}{c}\text { Type of Response } \\
\text { Variable }\end{array}$ & $\begin{array}{l}\text { Probability } \\
\text { Distribution }\end{array}$ & Statistical Approach & Modelling Technique \\
\hline \multirow{4}{*}{$\begin{array}{l}\text { Quantitative } \\
\text { (continuous) }\end{array}$} & \multirow[t]{2}{*}{ Gaussian } & Multiple regression & $\begin{array}{l}\text { WA, LS, LOWESS, GLM, } \\
\text { GAM, regression tree }\end{array}$ \\
\hline & & Ordination & CANOCO \\
\hline & Poisson & Multiple regression & GLM, GAM \\
\hline & Negative binomial & Multiple regression & GLM, GAM \\
\hline \multirow{2}{*}{$\begin{array}{l}\text { Semi-quantitative } \\
\text { (ordinal) }\end{array}$} & Discretized continuous & Multiple regression & PO model, CR model \\
\hline & True ordinal & Multiple regression & Stereotype model \\
\hline \multirow{8}{*}{$\begin{array}{l}\text { Qualitative (categorical, } \\
\text { nominal) }\end{array}$} & \multirow{4}{*}{ Multinomial } & Multiple regression & $\begin{array}{l}\text { Polychotomous logit } \\
\text { regression }\end{array}$ \\
\hline & & Classification & $\begin{array}{l}\text { Classification tree, MLC, } \\
\text { rule-based class }\end{array}$ \\
\hline & & Discriminant & DFA \\
\hline & & $\begin{array}{l}\text { Environmental } \\
\text { envelopes }\end{array}$ & $\begin{array}{l}\text { Boxcar, Convex Hull, } \\
\text { point-to-point metrics }\end{array}$ \\
\hline & \multirow{4}{*}{ Binomial } & Multiple regression & GLM, GAM, regression tree \\
\hline & & Classification & Classification tree \\
\hline & & $\begin{array}{l}\text { Environmental } \\
\text { envelopes }\end{array}$ & $\begin{array}{l}\text { Boxcar, Convex Hull, } \\
\text { point-to-point metrics }\end{array}$ \\
\hline & & Bayes & Bayes formula \\
\hline
\end{tabular}

\subsection{Strengths, Weaknesses, Opportunities, and Threats (SWOT) Analysis}

The most important strength of using ecological models is time saving for analysis, despite the possible large number and various types of input variables in the studies (Table 10). Second, researchers can use models to test hypotheses, to understand a studied system, and to define further research [93]. Ecological models can be used to conceptualize the relationships in ecosystems and, despite their limitations, they allow researchers to integrate expert knowledge in the modelling process, which in its turn is beneficial for management purposes. The third strength of using ecological models is that they can be used for any land-use scale or for a specific land-use type. Fourth, when land-use information is included in the models, a certain stressor can be related or traced to its source and the degree of its effect on the water bodies can be estimated. Moreover, as a categorical variable, land-use information can be easily quantified during a dedicated sampling campaign without specific equipment. Lastly, the ecological models are also widely applicable in terms of the methodology and results, and could facilitate communication between researchers and the public (e.g., studies by Van Sickle et al. [88], Alvarez-Mieles et al. [134]). 
Table 10. Strengths, Weaknesses, Opportunities, and Threats (SWOT) analysis for the use of models in studying land-use impacts on ecological water quality focusing on macroinvertebrates.

\begin{tabular}{|c|c|}
\hline Strengths & Weaknesses \\
\hline 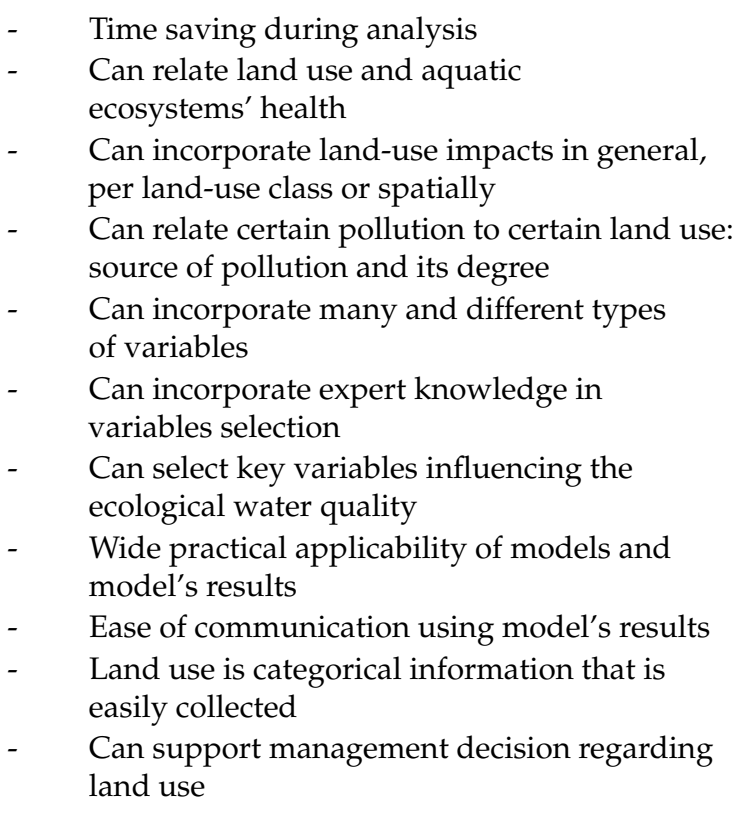 & 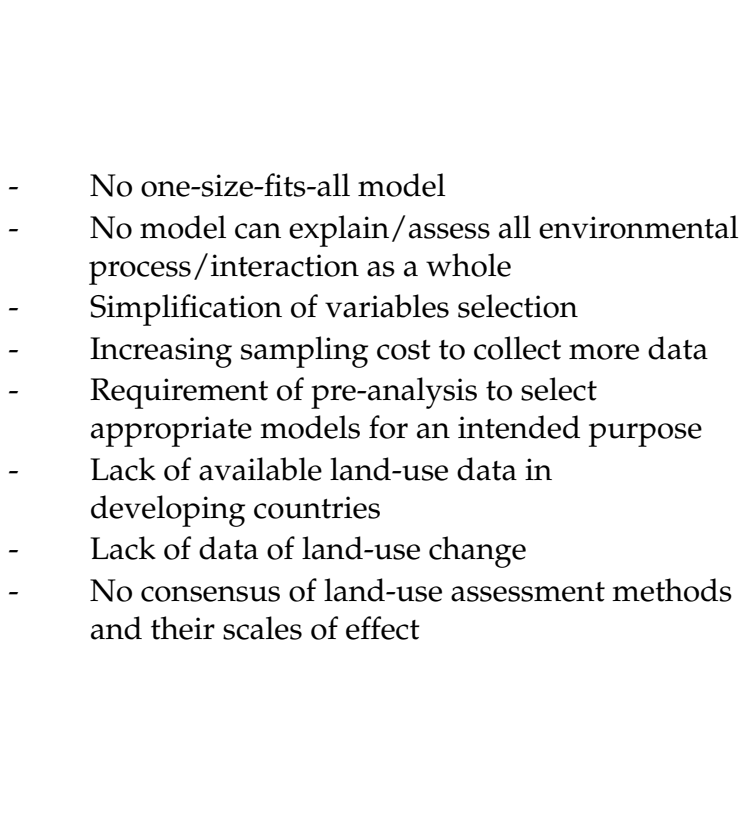 \\
\hline Opportunities & Threats \\
\hline $\begin{array}{l}\text { - } \\
\text { - } \quad \begin{array}{l}\text { } \text { model applinuous model development to improve } \\
\text { different purposes }\end{array} \\
\text { - } \begin{array}{l}\text { Ongoing capacity building in developed and } \\
\text { developing countries }\end{array} \\
\text { - } \\
\text { Availability of free software to run the models } \\
\text { Improvement of variables' qualities } \\
\text { and quantities } \\
\text { Higher awareness of land use as the source of } \\
\text { anthropogenic pollution } \\
\text { Increasing availability of land-use data in } \\
\text { developed and developing countries } \\
\text { Availability of different land-use assessment } \\
\text { methods and sources } \\
\text { Possibility to gather land-use data via new } \\
\text { technologies (e.g., drones) } \\
\text { Access to global databases }\end{array}$ & $\begin{array}{l}\text { - } \quad \text { Model's over- or under-fitting } \\
\text { - } \quad \text { Model's over simplification of reality } \\
\text { - } \quad \text { Use of less appropriate models may provide } \\
\text { misleading results } \\
\text { - } \quad \text { Over- and under-reliance of model's results } \\
\text { - } \quad \text { The newer the model the better } \\
\text { - } \quad \text { Use of outdated land-use data might not be } \\
\text { useful or may be misleading } \\
\text { - } \quad \text { Fast change of land use } \\
\text { Over simplification of land-use classification } \\
\text { may shield the real land-use effects }\end{array}$ \\
\hline
\end{tabular}

In the present research, we have identified several weaknesses of the use of models related to land use. First, due to the complexity of environmental processes, there is no model that can perfectly explain all environmental processes as a whole [133] and pre-analysis may be required to select an appropriate model. Second, models can simplify the selection process of model variables, which might result in final model containing variables that are less suitable based on general ecological knowledge. Third, since current ecological models can accommodate more input variables, sampling campaigns might require higher budgets to collect more data. Yet, financial means were not to be discussed in the current research. Fourth, available land use and land-use change information that can be collected via remote sensing and other sources is still lacking, especially in developing countries. Fifth, land-use 
data is not regularly updated, thus any possible land-use change and its effects are unknown. Besides, not all countries have all their land use registered, and in some cases the land use is recorded only when a specific sampling campaign is taking place. Lastly, there is no consensus regarding land-use assessment methods and their scale effects. Hence, studies on land-use effect are still lacking.

The first identified threat regarding the use of ecological models in ecological water quality studies is possible over- or under-fitting of the models compared to reality. This goes hand-in-hand with the nature of ecological models that over-simplify the reality [133]. The second threat is the use of less-appropriate models that may provide misleading results. Moreover, due to the ongoing development of models, researchers without sufficient knowledge in modelling might use more recent models instead of older ones which might threaten the proper use and proper selection of the models. Third, there is over- (where researchers accept the results of the models even though not all variables contained in the models are ecologically suitable) or under-reliance of models' results (where the results of the models are not accepted to support decision-making). Fourth, due to the lack of availability of land-use data to be accessed via remote sensing and other sources, sometimes researchers had to use outdated data that might not be useful in the analysis or may give a misleading result. After some time, a model also might not be applicable anymore on the area where land-use data were collected to develop the model, because land use tends to change quickly. Lastly, over-simplification of the land-use classifications to be included in the model may shield the real land-use effects in the model's results.

Despite the abovementioned weaknesses and threats, we have two main opportunities for using ecological models in studying land-use impacts (more detail in Table 10). The first obvious opportunity is related to model development. Model development to improve a model's applicability is ongoing, for instance via involving potential users from an early stage of the development process. Moreover, there are various models available for different ecological study purposes. Thus, the qualities and quantities of collected variables are also improved. Continuous model development is also supported by ongoing capacity building in both developed and developing countries. Free software, such as R [135], has also been developed to support modelling activities and is accessible worldwide. The second opportunity is related to land-use information. Nowadays, researchers are aware that land-use change has a potential anthropogenic impact on the aquatic system, and should be included when assessing multiple stressors conditions. Moreover, land-use data can be gathered in various ways, such as during a sampling campaign and by accessing the global databases (e.g., GRASS GIS [114]), thus increasing the availability of land-use information. New technologies, such as the use of drones to record land-use data, are promising and cost saving compared to a common manned-aircraft survey [136].

\section{Conclusions}

Land use can highly influence ecological water quality, but its information is often not included in ecological water quality studies. Since land use can influence the ecological water quality and it can change quickly, it is recommended to include land-use information in ecological water quality studies on both local and catchment scales. Various methods and sources to collect land-use information are available and are continuously developing; therefore, efforts need to be taken to collect land-use data through field observation, remote sensing, and other sources. Moreover, prior to selecting the most appropriate type of ecological models, one should exactly know what the aim of the study is, how the related research hypothesis is formulated, and what type of data are available. Despite models' limitation in explaining environmental processes as a whole, models can support a fast and quantitative analysis, especially when the influence of many variables needs to be evaluated. Developing countries can benefit from huge opportunities of using various ecological models to integrate land-use information in ecological water quality studies to support their decision-making. 
Acknowledgments: Minar Naomi Damanik-Ambarita was supported by the special research fund of Ghent University. Gert Everaert was supported by a post-doctoral fellowship from the Special Research Fund of Ghent University (BOF15/PDO/061) in Belgium.

Author Contributions: Minar Naomi Damanik-Ambarita, Gert Everaert, and Peter L.M. Goethals were involved in the article search and assessment and the paper writing.

Conflicts of Interest: The authors declare no conflict of interest.

\section{Appendix A}

Table A1. Negative effects of anthropogenic activities on different aspects of aquatic ecosystems, adapted from Carr and Neary [89].

\begin{tabular}{|c|c|c|c|c|c|c|}
\hline \multirow[b]{2}{*}{ Impacts } & \multicolumn{6}{|c|}{ Activities } \\
\hline & Agriculture & Urban & Forestry & $\begin{array}{c}\text { Hydropower } \\
\text { Generation and } \\
\text { Water Storage }\end{array}$ & Mining & Industries \\
\hline Sedimentation & $\sqrt{ }$ & $\sqrt{ }$ & $\sqrt{ }$ & $\sqrt{ }$ & $\sqrt{ }$ & $\sqrt{ }$ \\
\hline Eutrophication & $\sqrt{ }$ & $\sqrt{ }$ & $\sqrt{ }$ & $\sqrt{ }$ & $\sqrt{ }$ & $\sqrt{ }$ \\
\hline Thermal pollution & $\sqrt{ }$ & $\sqrt{ }$ & $\sqrt{ }$ & $\sqrt{ }$ & $\sqrt{ }$ & $\sqrt{ }$ \\
\hline Dissolved oxygen & & $\sqrt{ }$ & & $\sqrt{ }$ & $\sqrt{ }$ & $\sqrt{ }$ \\
\hline Acidification & & & & & $\sqrt{ }$ & $\sqrt{ }$ \\
\hline $\begin{array}{c}\text { Microbial } \\
\text { contamination }\end{array}$ & $\sqrt{ }$ & $\sqrt{ }$ & & & & \\
\hline Salinization & $\sqrt{ }$ & $\sqrt{ }$ & & & & $\sqrt{ }$ \\
\hline Metal pollution & $\sqrt{ }$ & $\sqrt{ }$ & & $\sqrt{ }$ & $\sqrt{ }$ & $\sqrt{ }$ \\
\hline Bio toxins & & & & & $\sqrt{ }$ & $\sqrt{ }$ \\
\hline Organic compounds & $\sqrt{ }$ & $\sqrt{ }$ & $\sqrt{ }$ & & & $\sqrt{ }$ \\
\hline $\begin{array}{c}\text { Micronutrient } \\
\text { depletion }\end{array}$ & & & & $\sqrt{ }$ & & \\
\hline
\end{tabular}

Table A2. Countries of studies, spatial scale and temporal aspects of land-use data in the ecological water quality studies.

\begin{tabular}{|c|c|c|c|c|c|c|}
\hline \multicolumn{2}{|c|}{ Country } & \multicolumn{3}{|c|}{ Spatial Scale } & \multirow[b]{2}{*}{ Temporal } & \multirow[b]{2}{*}{ Scenario } \\
\hline Developed & Developing & $\begin{array}{l}\text { Local or } \\
\text { Riparian }\end{array}$ & Catchment/Regional & Combined & & \\
\hline 31 & 8 & 21 & 7 & 11 & 2 & 5 \\
\hline
\end{tabular}

Table A3. Observation methods and sources utilized to acquire land-use data, based on the selected papers.

\begin{tabular}{cccccccc}
\hline $\begin{array}{c}\text { Remote } \\
\text { Sensing }\end{array}$ & $\begin{array}{c}\text { Field } \\
\text { Observation }\end{array}$ & GIS & $\begin{array}{c}\text { National } \\
\text { Database }\end{array}$ & $\begin{array}{c}\text { National Data }+ \\
\text { Satellite/GIS }\end{array}$ & $\begin{array}{c}\text { National Data } \\
+ \text { Field } \\
\text { Observation }\end{array}$ & $\begin{array}{c}\text { Field } \\
\text { Observation + } \\
\text { Satellite/GIS }\end{array}$ & $\begin{array}{c}\text { Satellite + GIS } \\
10\end{array}$ \\
5 & 9 & 6 & 4 & 2 & 2 & 1 \\
\hline
\end{tabular}

\section{References}

1. Pilgrim, C.M.; Mikhailova, E.A.; Post, C.J.; Hains, J.J. Spatial and temporal analysis of land cover changes and water quality in the Lake Issaqueena watershed, South Carolina. Environ. Monit. Assess. 2014, 186, 7617-7630. [CrossRef] [PubMed]

2. Garnier, J.; Brion, N.; Callens, J.; Passy, P.; Deligne, C.; Billen, G.; Servais, P.; Billen, C. Modeling historical changes in nutrient delivery and water quality of the Zenne River (1790s-2010): The role of land use, waterscape and urban wastewater management. J. Mar. Syst. 2013, 128, 62-76. [CrossRef]

3. Da Silva, M.V.D.; Rosa, B.F.J.V.; Alves, R.G. Effect of mesohabitats on responses of invertebrate community structure in streams under different land uses. Environ. Monit. Assess. 2015, 187, 714. [CrossRef] [PubMed]

4. Goss, C.W.; Goebel, P.C.; Sullivan, S.M.P. Shifts in attributes along agriculture-forest transitions of two streams in central Ohio, USA. Agric. Ecosyst. Environ. 2014, 197, 106-117. [CrossRef] 
5. Beasley, G.; Kneale, P. Reviewing the impact of metals and PAHs on macro invertebrates in urban watercourses. Prog. Phys. Geogr. 2002, 26, 236-270. [CrossRef]

6. Smucker, N.J.; Detenbeck, N.E. Meta-Analysis of Lost Ecosystem Attributes in Urban Streams and the Effectiveness of Out-of-Channel Management Practices. Restor. Ecol. 2014, 22, 741-748. [CrossRef]

7. Colin, N.; Maceda-Veiga, A.; Flor-Arnau, N.; Mora, J.; Fortuno, P.; Vieira, C.; Prat, N.; Cambra, J.; de Sostoa, A. Ecological impact and recovery of a Mediterranean river after receiving the effluent from a textile dyeing industry. Ecotoxicol. Environ. Saf. 2016, 132, 295-303. [CrossRef] [PubMed]

8. Raper, E.; Davies, S.; Perkins, B.; Lamb, H.; Hermanson, M.; Soares, A.; Stephenson, T. Ecological conditions of ponds situated on blast furnace slag deposits located in South Gare Site of Special Scientific Interest (SSSI), Teesside, UK. Environ. Geochem. Health 2015, 37, 545-556. [CrossRef] [PubMed]

9. Walsh, C.J.; Leonard, A.W.; Ladson, A.R.; Fletcher, T.D. Urban Stormwater and the Ecology of Streams; Cooperative Research Centre for Freshwater Ecology and Cooperative Research Centre for Catchment Hydrology: Canberra, Australia, 2004; ISBN 0-9751642-03.

10. Kehoe, L.; Kuemmerle, T.; Meyer, C.; Levers, C.; Vaclavik, T.; Kreft, H. Global patterns of agricultural land-use intensity and vertebrate diversity. Divers. Distrib. 2015, 21, 1308-1318. [CrossRef]

11. Roth, G.W. Crop Rotations and Conservation Tillage; College of Agricultural Sciences, The Pennsylvania State University: Pennsylvania, USA, 2017.

12. Yates, A.G.; Bailey, R.C.; Schwindt, J.A. No-till cultivation improves stream ecosystem quality. J. Soil Water Conserv. 2006, 61, 14-19.

13. Cortes, R.M.V.; Hughes, S.J.; Pereira, V.R.; Varandas, S.D.P. Tools for bioindicator assessment in rivers: The importance of spatial scale, land use patterns and biotic integration. Ecol. Indic. 2013, 34, 460-477. [CrossRef]

14. Manfrin, A.; Bombi, P.; Traversetti, L.; Larsen, S.; Scalici, M. A landscape-based predictive approach for running water quality assessment: A Mediterranean case study. J. Nat. Conserv. 2016, 30, 27-31. [CrossRef]

15. Thornhill, I.; Batty, L.; Death, R.G.; Friberg, N.R.; Ledger, M.E. Local and landscape scale determinants of macroinvertebrate assemblages and their conservation value in ponds across an urban land-use gradient. Biodivers. Conserv. 2017, 26, 1065-1086. [CrossRef]

16. Pietron, J.; Chalov, S.R.; Chalova, A.S.; Alekseenko, A.V.; Jarsjo, J. Extreme spatial variability in riverine sediment load inputs due to soil loss in surface mining areas of the Lake Baikal basin. Catena 2017, 152, 82-93. [CrossRef]

17. Alahuhta, J.; Virtala, A.; Hjort, J.; Ecke, F.; Johnson, L.B.; Sass, L.; Heino, J. Average niche breadths of species in lake macrophyte communities respond to ecological gradients variably in four regions on two continents. Oecologia 2017, 184, 219-235. [CrossRef] [PubMed]

18. Hook, S.E.; Kroon, F.J.; Metcalfe, S.; Greenfield, P.A.; Moncuquet, P.; McGrath, A.; Smith, R.; Warne, M.S.J.; Turner, R.D.; McKeown, A.; et al. Global transcriptomic profiling in barramundi (Lates calcarifer) from rivers impacted by differing agricultural land uses. Environ. Toxicol. Chem. 2017, 36, 103-112. [CrossRef] [PubMed]

19. Wright, R.F.; Couture, R.M.; Christiansen, A.B.; Guerrero, J.L.; Kaste, O.; Barlaup, B.T. Effects of multiple stresses hydropower, acid deposition and climate change on water chemistry and salmon populations in the River Otra, Norway. Sci. Total Environ. 2017, 574, 128-138. [CrossRef] [PubMed]

20. Baillie, B.R.; Neary, D.G. Water quality in New Zealand's planted forests: A review. N. Z. J. For. Sci. 2015, 45, 7. [CrossRef]

21. Gerth, W.J.; Li, J.; Giannico, G.R. Agricultural land use and macroinvertebrate assemblages in lowland temporary streams of the Willamette Valley, Oregon, USA. Agric. Ecosyst. Environ. 2017, 236, 154-165. [CrossRef]

22. Raapysjarvi, J.; Hamalainen, H.; Aroviita, J. Macrophytes in boreal streams: Characterizing and predicting native occurrence and abundance to assess human impact. Ecol. Indic. 2016, 64, 309-318. [CrossRef]

23. Liu, H.; Bu, H.M.; Liu, G.H.; Wang, Z.X.; Liu, W.Z. Effects of surrounding land use on metal accumulation in environments and submerged plants in subtropical ponds. Environ. Sci. Pollut. Res. 2015, 22, 18750-18758. [CrossRef] [PubMed] 
24. Bonada, N.; Rieradevall, M.; Dallas, H.; Davis, J.; Day, J.; Figueroa, R.; Resh, V.H.; Prat, N. Multi-scale assessment of macroinvertebrate richness and composition in Mediterranean-climate rivers. Freshw. Biol. 2008, 53, 772-788. [CrossRef]

25. Brown, L.R.; May, J.T.; Wulff, M. Associations of Benthic Macroinvertebrate Assemblages with Environmental Variables in the Upper Clear Creek Watershed, California. West. N. Am. Nat. 2012, 72, 473-494. [CrossRef]

26. Yang, Y.Y.; Toor, G.S. Sources and mechanisms of nitrate and orthophosphate transport in urban stormwater runoff from residential catchments. Water Res. 2017, 112, 176-184. [CrossRef] [PubMed]

27. Lee, F.; Simon, K.S.; Perry, G.L.W. Increasing agricultural land use is associated with the spread of an invasive fish (Gambusia affinis). Sci. Total Environ. 2017, 586, 1113-1123. [CrossRef] [PubMed]

28. Brogna, D.; Michez, A.; Jacobs, S.; Dufrene, M.; Vincke, C.; Dendoncker, N. Linking Forest Cover to Water Quality: A Multivariate Analysis of Large Monitoring Datasets. Water 2017, 9, 176. [CrossRef]

29. Cunha, E.J.; Montag, L.F.D.; Juen, L. Oil palm crops effects on environmental integrity of Amazonian streams and Heteropteran (Hemiptera) species diversity. Ecol. Indic. 2015, 52, 422-429. [CrossRef]

30. Epele, L.B.; Miserendino, M.L. Environmental Quality and Aquatic Invertebrate Metrics Relationships at Patagonian Wetlands Subjected to Livestock Grazing Pressures. PLoS ONE 2015, 10, e0137873. [CrossRef] [PubMed]

31. Sueyoshi, M.; Ishiyama, N.; Nakamura, F. beta-diversity decline of aquatic insects at the microhabitat scale associated with agricultural land use. Landsc. Ecol. Eng. 2016, 12, 187-196. [CrossRef]

32. Palmer, M.A.; Menninger, H.L.; Bernhardt, E. River restoration, habitat heterogeneity and biodiversity: A failure of theory or practice? Freshw. Biol. 2010, 55, 205-222. [CrossRef]

33. Palmer, M.A.; Hondula, K.L.; Koch, B.J. Ecological Restoration of Streams and Rivers: Shifting Strategies and Shifting Goals. Annu. Rev. Ecol. Evol. Syst. 2014, 45, 247-269. [CrossRef]

34. Berger, E.; Haase, P.; Kuemmerlen, M.; Leps, M.; Schafer, R.B.; Sundermann, A. Water quality variables and pollution sources shaping stream macroinvertebrate communities. Sci. Total Environ. 2017, 587, 1-10. [CrossRef] [PubMed]

35. Shrestha, M.K.; Recknagel, F.; Frizenschaf, J.; Meyer, W. Future climate and land uses effects on flow and nutrient loads of a Mediterranean catchment in South Australia. Sci. Total Environ. 2017, 590, 186-193. [CrossRef] [PubMed]

36. Bussi, G.; Janes, V.; Whitehead, P.G.; Dadson, S.J.; Holman, I.P. Dynamic response of land use and river nutrient concentration to long-term climatic changes. Sci. Total Environ. 2017, 590, 818-831. [CrossRef] [PubMed]

37. Fierro, P.; Bertran, C.; Mercado, M.; Pena-Cortes, F.; Tapia, J.; Hauenstein, E.; Caputo, L.; Vargas-Chacoff, L. Landscape composition as a determinant of diversity and functional feeding groups of aquatic macroinvertebrates in southern rivers of the Araucania, Chile. Lat. Am. J. Aquat. Res. 2015, 43, 186-200. [CrossRef]

38. Jun, Y.C.; Kim, N.Y.; Kwon, S.J.; Han, S.C.; Hwang, I.C.; Park, J.H.; Won, D.H.; Byun, M.S.; Kong, H.Y.; Lee, J.E.; et al. Effects of land use on benthic macroinvertebrate communities: Comparison of two mountain streams in Korea. Ann. Limnol.-Int. J. Limnol. 2011, 47, S35-S49. [CrossRef]

39. Park, S.R.; Lee, H.J.; Lee, S.W.; Hwang, S.J.; Byeon, M.S.; Joo, G.J.; Jeong, K.S.; Kong, D.S.; Kim, M.C. Relationships between land use and multi-dimensional characteristics of streams and rivers at two different scales. Ann. Limnol.-Int. J. Limnol. 2011, 47, S107-S116. [CrossRef]

40. Hughes, S.J.; Cabral, J.A.; Bastos, R.; Cortes, R.; Vicente, J.; Eitelberg, D.; Yu, H.R.; Honrado, J.; Santos, M. A stochastic dynamic model to assess land use change scenarios on the ecological status of fluvial water bodies under the Water Framework Directive. Sci. Total Environ. 2016, 565, 427-439. [CrossRef] [PubMed]

41. Schmalz, B.; Kuemmerlen, M.; Kiesel, J.; Cai, Q.; Jahnig, S.C.; Fohrer, N. Impacts of land use changes on hydrological components and macroinvertebrate distributions in the Poyang lake area. Ecohydrology 2015, 8, 1119-1136. [CrossRef]

42. Tu, J. Combined impact of climate and land use changes on streamflow and water quality in eastern Massachusetts, USA. J. Hydrol. 2009, 379, 268-283. [CrossRef]

43. McDonald, R.I.; Weber, K.F.; Padowski, J.; Boucher, T.; Shemie, D. Estimating watershed degradation over the last century and its impact on water-treatment costs for the world's large cities. Proc. Natl. Acad. Sci. USA 2016, 113, 9117-9122. [CrossRef] [PubMed] 
44. Bucker, A.; Sondermann, M.; Frede, H.G.; Breuer, L. The influence of land-use on macroinvertebrate communities in montane tropical streams-A case study from Ecuador. Fundam. Appl. Limnol. 2010, 177, 267-282. [CrossRef]

45. Mwedzi, T.; Bere, T.; Mangadze, T. Macroinvertebrate assemblages in agricultural, mining, and urban tropical streams: Implications for conservation and management. Environ. Sci. Pollut. Res. 2016, 23, 11181-11192. [CrossRef] [PubMed]

46. Strehmel, A.; Schmalz, B.; Fohrer, N. Evaluation of Land Use, Land Management and Soil Conservation Strategies to Reduce Non-Point Source Pollution Loads in the Three Gorges Region, China. Environ. Manag. 2016, 58, 906-921. [CrossRef] [PubMed]

47. Everaert, G.; Pauwels, I.S.; Boets, P.; Verduin, E.; de la Haye, M.A.A.; Blom, C.; Goethals, P.L.M. Model-based evaluation of ecological bank design and management in the scope of the European Water Framework Directive. Ecol. Eng. 2013, 53, 144-152. [CrossRef]

48. Arias-Hidalgo, M.; Villa-Cox, G.; Griensven, A.V.; Solorzano, G.; Villa-Cox, R.; Mynett, A.E.; Debels, P. A decision framework for wetland management in a river basin context: The "Abras de Mantequilla" case study in the Guayas River Basin, Ecuador. Environ. Sci. Policy 2013, 34, 103-114. [CrossRef]

49. Schuwirth, N.; Dietzel, A.; Reichert, P. The importance of biotic interactions for the prediction of macroinvertebrate communities under multiple stressors. Funct. Ecol. 2016, 30, 974-984. [CrossRef]

50. Tchakonte, S.; Ajeagah, G.A.; Camara, A.I.; Diomande, D.; Tchatcho, N.L.N.; Ngassam, P. Impact of urbanization on aquatic insect assemblages in the coastal zone of Cameroon: The use of biotraits and indicator taxa to assess environmental pollution. Hydrobiologia 2015, 755, 123-144. [CrossRef]

51. Slevers, M.; Hale, R.; Morrongiello, J.R. Do trout respond to riparian change? A meta-analysis with implications for restoration and management. Freshw. Biol. 2017, 62, 445-457. [CrossRef]

52. Ferreira, A.R.L.; Fernandes, L.F.S.; Cortes, R.M.V.; Pacheco, F.A.L. Assessing anthropogenic impacts on riverine ecosystems using nested partial least squares regression. Sci. Total Environ. 2017, 583, 466-477. [CrossRef] [PubMed]

53. Larras, F.; Coulaud, R.; Gautreau, E.; Billoir, E.; Rosebery, J.; Usseglio-Polatera, P. Assessing anthropogenic pressures on streams: A random forest approach based on benthic diatom communities. Sci. Total Environ. 2017, 586, 1101-1112. [CrossRef] [PubMed]

54. Dahm, V.; Hering, D. A modeling approach for identifying recolonisation source sites in river restoration planning. Landsc. Ecol. 2016, 31, 2323-2342. [CrossRef]

55. Pearson, C.E.; Ormerod, S.J.; Symondson, W.O.C.; Vaughan, I.P. Resolving large-scale pressures on species and ecosystems: Propensity modelling identifies agricultural effects on streams. J. Appl. Ecol. 2016, 53, 408-417. [CrossRef] [PubMed]

56. Weigel, B.M. Development of stream macroinvertebrate models that predict watershed and local stressors in Wisconsin. J. N. Am. Benthol. Soc. 2003, 22, 123-142. [CrossRef]

57. Abouali, M.; Nejadhashemi, A.P.; Daneshvar, F.; Woznicki, S.A. Two-phase approach to improve stream health modeling. Ecol. Inform. 2016, 34, 13-21. [CrossRef]

58. Alemneh, T.; Ambelu, A.; Bahrndorff, S.; Mereta, S.T.; Pertoldi, C.; Zaitchik, B.F. Modeling the impact of highland settlements on ecological disturbance of streams in Choke Mountain Catchment: Macroinvertebrate assemblages and water quality. Ecol. Indic. 2017, 73, 452-459. [CrossRef]

59. Alvarez-Cabria, M.; Gonzalez-Ferreras, A.M.; Penas, F.J.; Barquin, J. Modelling macroinvertebrate and fish biotic indices: From reaches to entire river networks. Sci. Total Environ. 2017, 577, 308-318. [CrossRef] [PubMed]

60. Baltazar, D.E.S.; Magcale-Macandog, D.; Tan, M.F.O.; Zafaralla, M.T.; Cadiz, N.M. A River Health Status Model Based on Water Quality, Macroinvertebrates and Land Use for Niyugan River, Cabuyao City, Laguna, Philippines. J. Environ. Sci. Manag. 2016, 19, 38-53.

61. Damanik-Ambarita, M.N.; Everaert, G.; Forio, M.A.E.; Nguyen, T.H.T.; Lock, K.; Musonge, P.L.S.; Suhareva, N.; Dominguez-Granda, L.; Bennetsen, E.; Boets, P.; et al. Generalized Linear Models to Identify Key Hydromorphological and Chemical Variables Determining the Occurrence of Macroinvertebrates in the Guayas River Basin (Ecuador). Water 2016, 8, 297. [CrossRef]

62. Einheuser, M.D.; Nejadhashemi, A.P.; Sowa, S.P.; Wang, L.Z.; Hamaamin, Y.A.; Woznicki, S.A. Modeling the effects of conservation practices on stream health. Sci. Total Environ. 2012, 435, 380-391. [CrossRef] [PubMed] 
63. Erba, S.; Pace, G.; Demartini, D.; Di Pasquale, D.; Dorflinger, G.; Buffagni, A. Land use at the reach scale as a major determinant for benthic invertebrate community in Mediterranean rivers of Cyprus. Ecol. Indic. 2015, 48, 477-491. [CrossRef]

64. Forio, M.A.E.; Landuyt, D.; Bennetsen, E.; Lock, K.; Nguyen, T.H.T.; Damanik-Ambarita, M.N.; Musonge, P.L.S.; Boets, P.; Everaert, G.; Dominguez-Granda, L.; et al. Bayesian belief network models to analyse and predict ecological water quality in rivers. Ecol. Model. 2015, 312, 222-238. [CrossRef]

65. Forio, M.A.E.; Mouton, A.; Lock, K.; Boets, P.; Tien, N.T.H.; Damanik-Ambarita, M.N.; Musonge, P.L.S.; Dominguez-Granda, L.; Goethals, P.L.M. Fuzzy modelling to identify key drivers of ecological water quality to support decision and policy making. Environ. Sci. Policy 2017, 67, 58-68. [CrossRef]

66. Hrodey, P.J.; Sutton, T.M.; Frimpong, E.A.; Simon, T.P. Land-use Impacts on Watershed Health and Integrity in Indiana Warmwater Streams. Am. Midl. Nat. 2009, 161, 76-95. [CrossRef]

67. Mantyka-Pringle, C.S.; Martin, T.G.; Moffatt, D.B.; Linke, S.; Rhodes, J.R. Understanding and predicting the combined effects of climate change and land-use change on freshwater macroinvertebrates and fish. J. Appl. Ecol. 2014, 51, 572-581. [CrossRef]

68. Moreno, P.; Franca, J.S.; Ferreira, W.R.; Paz, A.D.; Monteiro, I.M.; Callisto, M. Use of the BEAST model for biomonitoring water quality in a neotropical basin. Hydrobiologia 2009, 630, 231-242. [CrossRef]

69. Sanchez, G.M.; Nejadhashemi, A.P.; Zhang, Z.; Woznicki, S.A.; Habron, G.; Marquart-Pyatt, S.; Shortridge, A. Development of a socio-ecological environmental justice model for watershed-based management. J. Hydrol. 2014, 518, 162-177. [CrossRef]

70. Sheldon, F.; Peterson, E.E.; Boone, E.L.; Sippel, S.; Bunn, S.E.; Harch, B.D. Identifying the spatial scale of land use that most strongly influences overall river ecosystem health score. Ecol. Appl. 2012, 22, 2188-2203. [CrossRef] [PubMed]

71. Woznicki, S.A.; Nejadhashemi, A.P.; Abouali, M.; Herman, M.R.; Esfahanian, E.; Hamaamin, Y.A.; Zhang, Z. Ecohydrological modeling for large-scale environmental impact assessment. Sci. Total Environ. 2016, 543, 274-286. [CrossRef] [PubMed]

72. Zhang, Y.X.; Dudgeon, D.; Cheng, D.S.; Thoe, W.; Fok, L.; Wang, Z.Y.; Lee, J.H.W. Impacts of land use and water quality on macroinvertebrate communities in the Pearl River drainage basin, China. Hydrobiologia 2010, 652, 71-88. [CrossRef]

73. Barton, D.R. The use of Percent Model Affinity to assess the effects of agriculture on benthic invertebrate communities in headwater streams of southern Ontario, Canada. Freshw. Biol. 1996, 36, 397-410. [CrossRef]

74. Bennetsen, E.; Gobeyn, S.; Goethals, P.L.M. Species distribution models grounded in ecological theory for decision support in river management. Ecol. Model. 2016, 325, 1-12. [CrossRef]

75. Carlisle, D.M.; Hawkins, C.P. Land use and the structure of western US stream invertebrate assemblages: Predictive models and ecological traits. J. N. Am. Benthol. Soc. 2008, 27, 986-999. [CrossRef]

76. Carlisle, D.M.; Meador, M.R. A biological assessment of streams in the eastern united states using a predictive model for macroinvertebrate assemblages. J. Am. Water Resour. Assoc. 2007, 43, 1194-1207. [CrossRef]

77. Clapcott, J.E.; Goodwin, E.O.; Snelder, T.H.; Collier, K.J.; Neale, M.W.; Greenfield, S. Finding reference: A comparison of modelling approaches for predicting macroinvertebrate community index benchmarks. N. Z. J. Mar. Freshw. Res. 2017, 51, 44-59. [CrossRef]

78. Davies, S.P.; Jackson, S.K. The biological condition gradient: A descriptive model for interpreting change in aquatic ecosystems. Ecol. Appl. 2006, 16, 1251-1266. [CrossRef]

79. Feio, M.J.; Norris, R.H.; Graca, M.A.S.; Nichols, S. Water quality assessment of Portuguese streams: Regional or national predictive models? Ecol. Indic. 2009, 9, 791-806. [CrossRef]

80. Feio, M.J.; Reynoldson, T.B.; Ferreira, V.; Graca, M.A.S. A predictive model for freshwater bioassessment (Mondego River, Portugal). Hydrobiologia 2007, 589, 55-68. [CrossRef]

81. Guse, B.; Kail, J.; Radinger, J.; Schroder, M.; Kiesel, J.; Hering, D.; Wolter, C.; Fohrer, N. Eco-hydrologic model cascades: Simulating land use and climate change impacts on hydrology, hydraulics and habitats for fish and macroinvertebrates. Sci. Total Environ. 2015, 533, 542-556. [CrossRef] [PubMed]

82. Hawkins, C.P.; Norris, R.H.; Hogue, J.N.; Feminella, J.W. Development and evaluation of predictive models for measuring the biological integrity of streams. Ecol. Appl. 2000, 10, 1456-1477. [CrossRef]

83. Hawkins, C.P.; Yuan, L.L. Multitaxon distribution models reveal severe alteration in the regional biodiversity of freshwater invertebrates. Freshw. Sci. 2016, 35, 1365-1376. [CrossRef] 
84. Maloney, K.O.; Weller, D.E. Anthropogenic disturbance and streams: Land use and land-use change affect stream ecosystems via multiple pathways. Freshw. Biol. 2011, 56, 611-626. [CrossRef]

85. Terrado, M.; Sabater, S.; Chaplin-Kramer, B.; Mandle, L.; Ziv, G.; Acuna, V. Model development for the assessment of terrestrial and aquatic habitat quality in conservation planning. Sci. Total Environ. 2016, 540, 63-70. [CrossRef] [PubMed]

86. Lock, K.; Goethals, P.L.M. Habitat suitability modelling for mayflies (Ephemeroptera) in Flanders (Belgium). Ecol. Inform. 2013, 17, 30-35. [CrossRef]

87. Lock, K.; Goethals, P.L.M. Predicting the occurrence of stoneflies (Plecoptera) on the basis of water characteristics, river morphology and land use. J. Hydroinform. 2014, 16, 812-821. [CrossRef]

88. Van Sickle, J.; Baker, J.; Herlihy, A.; Bayley, P.; Gregory, S.; Haggerty, P.; Ashkenas, L.; Li, J. Projecting the biological condition of streams under alternative scenarios of human land use. Ecol. Appl. 2004, 14, 368-380. [CrossRef]

89. Carr, G.M.; Neary, J.P. Water Quality for Ecosystem and Human Health, 2nd ed.; Robarts, R., Barker, S., Eds.; United Nations Environment Programme (UNEP); Global Environment Monitoring System (GEMS)/Water Programme: Burlington, ON, Canada, 2008; p. 120. ISBN 92-95039-51-7.

90. Kuemmerle, T.; Erb, K.; Meyfroidt, P.; Muller, D.; Verburg, P.H.; Estel, S.; Haberl, H.; Hostert, P.; Jepsen, M.R.; Kastner, T.; et al. Challenges and opportunities in mapping land use intensity gIobally. Curr. Opin. Environ. Sustain. 2013, 5, 484-493. [CrossRef] [PubMed]

91. Crétaz, A.L.D.L.; Barten, P.K. Land Use Effects on Streamflow and Water Quality in the Northeastern United States; CRC: Boca Raton, FL, USA, 2007; p. 319. ISBN 9780849391873, 0849391873.

92. Rios-Touma, B.; Prescott, C.; Axtell, S.; Kondolf, G.M. Habitat Restoration in the Context of Watershed Prioritization: The Ecological Performance of Urban Stream Restoration Projects in Portland, Oregon. River Res. Appl. 2015, 31, 755-766. [CrossRef]

93. Waite, I.R. Agricultural disturbance response models for invertebrate and algal metrics from streams at two spatial scales within the U.S. Hydrobiologia 2014, 726, 285-303. [CrossRef]

94. Molina, M.C.; Roa-Fuentes, C.A.; Zeni, J.O.; Casatti, L. The effects of land use at different spatial scales on instream features in agricultural streams. Limnologica 2017, 65, 14-21. [CrossRef]

95. Usio, N.; Nakagawa, M.; Aoki, T.; Higuchi, S.; Kadono, Y.; Akasaka, M.; Takamura, N. Effects of land use on trophic states and multi-taxonomic diversity in Japanese farm ponds. Agric. Ecosyst. Environ. 2017, 247, 205-215. [CrossRef]

96. Lee, B.Y.; Park, S.J.; Paule, M.C.; Jun, W.; Lee, C.H. Effects of Impervious Cover on the Surface Water Quality and Aquatic Ecosystem of the Kyeongan Stream in South Korea. Water Environ. Res. 2012, 84, 635-645. [CrossRef] [PubMed]

97. Wen, T.; Sheng, S.; An, S.Q. Relationships between stream ecosystem properties and landscape composition at multiple spatial scales along a heavily polluted stream in China: Implications for restoration. Ecol. Eng. 2016, 97, 493-502. [CrossRef]

98. De Morais, L.; de Oliveira Sanches, B.; Sanches, B.D.O.; Kaufmann, P.R.; Hughes, R.M.; Molozzi, J.; Callisto, M. Assessment of disturbance at three spatial scales in two large tropical reservoirs. J. Limnol. 2017, 76, 240-252. [CrossRef]

99. Raymond, K.L.; Vondracek, B. Relationships among rotational and conventional grazing systems, stream channels, and macroinvertebrates. Hydrobiologia 2011, 669, 105-117. [CrossRef]

100. Jayawardana, J.M.C.K.; Gunawardana, W.D.T.M.; Udayakumara, E.P.N.; Westbrooke, M. Land use impacts on river health of Uma Oya, Sri Lanka: Implications of spatial scales. Environ. Monit. Assess. 2017, 189. [CrossRef] [PubMed]

101. Merriam, E.R.; Petty, J.T.; Merovich, G.T.; Fulton, J.B.; Strager, M.P. Additive effects of mining and residential development on stream conditions in a central Appalachian watershed. J. N. Am. Benthol. Soc. 2011, 30, 399-418. [CrossRef]

102. Meyer, M.D.; Davis, C.A.; Dvorett, D. Response of Wetland Invertebrate Communities to Local and Landscape Factors in North Central Oklahoma. Wetlands 2015, 35, 533-546. [CrossRef]

103. Carvalho, L.; Cortes, R.; Bordalo, A.A. Evaluation of the ecological status of an impaired watershed by using a multi-index approach. Environ. Monit. Assess. 2011, 174, 493-508. [CrossRef] [PubMed]

104. Bellucci, C.J.; Becker, M.; Beauchene, M. Characteristics of Macroinvertebrate and Fish Communities From 30 Least Disturbed Small Streams in Connecticut. Northeast. Nat. 2011, 18, 411-444. [CrossRef] 
105. Lowrance, R.; Altier, L.S.; Newbold, J.D.; Schnabel, R.R.; Groffman, P.M.; Denver, J.M.; Correll, D.L.; Gilliam, J.W.; Robinson, J.L.; Brinsfield, R.B.; et al. Water quality functions of riparian forest buffers in Chesapeake Bay watersheds. Environ. Manag. 1997, 21, 687-712. [CrossRef]

106. Rocchini, D.; Petras, V.; Petrasova, A.; Horning, N.; Furtkevicova, L.; Neteler, M.; Leutner, B.; Wegmann, M. Open data and open source for remote sensing training in ecology. Ecol. Inform. 2017, 40, 57-61. [CrossRef]

107. Harding, J.S.; Benfield, E.F.; Bolstad, P.V.; Helfman, G.S.; Jones, E.B.D. Stream biodiversity: The ghost of land use past. Proc. Natl. Acad. Sci. USA 1998, 95, 14843-14847. [CrossRef] [PubMed]

108. Verkaik, I.; Vila-Escale, M.; Rieradevall, M.; Baxter, C.V.; Lake, P.S.; Minshall, G.W.; Reich, P.; Prat, N. Stream macroinvertebrate community responses to fire: Are they the same in different fire-prone biogeographic regions? Freshw. Sci. 2015, 34, 1527-1541. [CrossRef]

109. Strauch, A.M.; MacKenzie, R.A.; Giardina, C.P.; Bruland, G.L. Climate driven changes to rainfall and streamflow patterns in a model tropical island hydrological system. J. Hydrol. 2015, 523, 160-169. [CrossRef]

110. Barber, L.B.; Paschke, S.S.; Battaglia, W.A.; Douville, C.; Fitzgerald, K.C.; Keefe, S.H.; Roth, D.A.; Vajda, A.M. Effects of an Extreme Flood on Trace Elements in River Water-From Urban Stream to Major River Basin. Environ. Sci. Technol. 2017, 51, 10344-10356. [CrossRef] [PubMed]

111. Milliman, J.D.; Lee, T.Y.; Huang, J.C.; Kao, S.J. Impact of catastrophic events on small mountainous rivers: Temporal and spatial variations in suspendedand dissolved-solid fluxes along the Choshui River, central western Taiwan, during typhoon Mindulle, 2-6 July 2004. Geochim. Cosmochim. Acta 2017, 205, 272-294. [CrossRef]

112. Lofgren, S.; Grandin, U.; Stendera, S. Long-term effects on nitrogen and benthic fauna of extreme weather events: Examples from two Swedish headwater streams. Ambio 2014, 43, 58-76. [CrossRef] [PubMed]

113. Bixby, R.J.; Cooper, S.D.; Gresswell, R.E.; Brown, L.E.; Dahm, C.N.; Dwire, K.A. Fire effects on aquatic ecosystems: An assessment of the current state of the science. Freshw. Sci. 2015, 34, 1340-1350. [CrossRef]

114. Rocchini, D.; Petras, V.; Petrasova, A.; Chemin, Y.; Ricotta, C.; Frigeri, A.; Landa, M.; Marcantonio, M.; Bastin, L.; Metz, M.; et al. Spatio-ecological complexity measures in GRASS GIS. Comput. Geosci. 2017, 104, 166-176. [CrossRef]

115. Greenacre, M.; Primicerio, R. Multivariate Analysis of Ecological Data; Fundación BBVA: Bilbao, Spain, 2013; ISBN 978-84-92937-50-9.

116. Crawley, M.J. The R Book; Wiley: Chichester, UK, 2007; Volume viii, p. 942. ISBN 9780470510247, 0470510242.

117. Zuur, A.F.; Ieno, E.N.; Smith, G.M. Analysing Ecological Data; Statistics for biology and health; Springer: New York, NY, USA, 2007; Volume xxvi, p. 672. ISBN 9780387459677 (hbk.).

118. Paliy, O.; Shankar, V. Application of multivariate statistical techniques in microbial ecology. Mol. Ecol. 2016, 25, 1032-1057. [CrossRef] [PubMed]

119. Dalgaard, P. Introductory Statistics with R, 2nd ed.; Statistics and computing; Springer: New York, NY, USA, 2008; Volume xvi, p. 363. ISBN 9780387790534 (pbk. alk. paper), 0387790535 (pbk. alk. paper) 1431-8784.

120. Tuffery, S. Data Mining and Statistics for Decision Making; Wiley series in computational statistics; Wiley: Chichester, UK; Hoboken, NJ, USA, 2011; Volume xxiv, p. 689. ISBN 9780470688298 (hardback).

121. Berk, R.A. Statistical Learning from a Regression Perspective; Springer series in statistics; Springer Verlag: New York, NY, USA, 2008; Volume xvii, p. 358. ISBN 9780387775005, 0387775005.

122. Van Echelpoel, W.; Boets, P.; Landuyt, D.; Gobeyn, S.; Everaert, G.; Bennetsen, E.; Mouton, A.; Goethals, P.L.M. Species distribution models for sustainable ecosystem management. Adv. Model. Tech. Stud. Glob. Chang. Environ. Sci. 2015, 27, 115-134. [CrossRef]

123. Zuur, A.F.; Ieno, E.N.; Elphick, C.S. A protocol for data exploration to avoid common statistical problems. Methods Ecol. Evol. 2010, 1, 3-14. [CrossRef]

124. Witten, I.H.; Frank, E. Data Mining: Practical Machine Learning Tools and Techniques, 2nd ed.; Morgan Kaufmann series in data management systems; Morgan Kaufman: Amsterdam, The Netherlands; Boston, MA, USA, 2005; Volume xxxi, p. 525. ISBN 0120884070.

125. Shmueli, G. To Explain or to Predict? Stat. Sci. 2010, 25, 289-310. [CrossRef]

126. Zuur, A.F. Mixed Effects Models and Extensions in Ecology with R; Statistics for biology and health; Springer: New York, NY, USA, 2009; Volume xxii, p. 574. ISBN 9780387874579 (hbk.), 0387874577 (hbk.).

127. Damanik-Ambarita, M.N.; Lock, K.; Boets, P.; Everaert, G.; Nguyen, T.H.T.; Forio, M.A.E.; Musonge, P.L.S.; Suhareva, N.; Bennetsen, E.; Landuyt, D.; et al. Ecological water quality analysis of the Guayas river basin (Ecuador) based on macroinvertebrates indices. Limnologica 2016. [CrossRef] 
128. Cereghino, R.; Giraudel, J.L.; Compin, A. Spatial analysis of stream invertebrates distribution in the Adour-Garonne drainage basin (France), using Kohonen self organizing maps. Ecol. Model. 2001, 146, 167-180. [CrossRef]

129. Goethals, P.L.M.; Dedecker, A.P.; Gabriels, W.; Lek, S.; De Pauw, N. Applications of artificial neural networks predicting macroinvertebrates in freshwaters. Aquat. Ecol. 2007, 41, 491-508. [CrossRef]

130. Yang, L.; Bai, X.; Hu, Y. Comparison between the linear model and k-nearest neighbor method for predicting macroinvertebrate assemblages in a city river in Beijing, China. Appl. Ecol. Environ. Res. 2017, 16, 387-406. [CrossRef]

131. Nirmalakhandan, N. Modeling Tools for Environmental Engineers and Scientists; CRC Press: Boca Raton, FL, USA, 2002; Volume xi, p. 312. ISBN 1566769957.

132. Paillex, A.; Reichert, P.; Lorenz, A.W.; Schuwirth, N. Mechanistic modelling for predicting the effects of restoration, invasion and pollution on benthic macroinvertebrate communities in rivers. Freshw. Biol. 2017, 62, 1083-1093. [CrossRef]

133. Guisan, A.; Zimmermann, N.E. Predictive habitat distribution models in ecology. Ecol. Model. 2000, 135, 147-186. [CrossRef]

134. Alvarez-Mieles, G.; Irvine, K.; Griensven, A.V.; Arias-Hidalgo, M.; Torres, A.; Mynett, A.E. Relationships between aquatic biotic communities and water quality in a tropical river-wetland system (Ecuador). Environ. Sci. Policy 2013, 34, 115-127. [CrossRef]

135. R-Core-Team. R: A Language and Environment for Statistical Computing; R Foundation for Statistical Computing: Vienna, Austria, 2013.

136. Hubbart, J.A.; Kellner, E.; Kinder, P.; Stephan, K. Challenges in aquatic physical habitat assessment: Improving conservation and restoration decisions for contemporary watersheds. Challenges 2017, 8, 11. [CrossRef]

(C) 2018 by the authors. Licensee MDPI, Basel, Switzerland. This article is an open access article distributed under the terms and conditions of the Creative Commons Attribution (CC BY) license (http:/ / creativecommons.org/licenses/by/4.0/). 